\title{
Biomass and lipid induction strategies in microalgae for biofuel production and other applications
}

\author{
Hossein Alishah Aratboni ${ }^{1,2+}$, Nahid Rafiei ${ }^{1,2,3+}$, Raul Garcia-Granados ${ }^{2,4}$, Abbas Alemzadeh ${ }^{3}$ \\ and José Rubén Morones-Ramírez ${ }^{1,2^{*}}$ (D)
}

\begin{abstract}
The use of fossil fuels has been strongly related to critical problems currently affecting society, such as: global warming, global greenhouse effects and pollution. These problems have affected the homeostasis of living organisms worldwide at an alarming rate. Due to this, it is imperative to look for alternatives to the use of fossil fuels and one of the relevant substitutes are biofuels. There are different types of biofuels (categories and generations) that have been previously explored, but recently, the use of microalgae has been strongly considered for the production of biofuels since they present a series of advantages over other biofuel production sources: (a) they don't need arable land to grow and therefore do not compete with food crops (like biofuels produced from corn, sugar cane and other plants) and; (b) they exhibit rapid biomass production containing high oil contents, at least 15 to 20 times higher than land based oleaginous crops. Hence, these unicellular photosynthetic microorganisms have received great attention from researches to use them in the large-scale production of biofuels. However, one disadvantage of using microalgae is the high economic cost due to the low-yields of lipid content in the microalgae biomass. Thus, development of different methods to enhance microalgae biomass, as well as lipid content in the microalgae cells, would lead to the development of a sustainable low-cost process to produce biofuels. Within the last 10 years, many studies have reported different methods and strategies to induce lipid production to obtain higher lipid accumulation in the biomass of microalgae cells; however, there is not a comprehensive review in the literature that highlights, compares and discusses these strategies. Here, we review these strategies which include modulating light intensity in cultures, controlling and varying $\mathrm{CO}_{2}$ levels and temperature, inducing nutrient starvation in the culture, the implementation of stress by incorporating heavy metal or inducing a high salinity condition, and the use of metabolic and genetic engineering techniques coupled with nanotechnology.
\end{abstract}

Keywords: Global warming, Biofuel, Microalgae, Nanoparticle, Metabolic genetic engineering, Lipid production

\section{Introduction}

Recent reports from the Department of Economic and Social Affairs (DESA) show that the global human population is growing at alarming rates, predicting the world

*Correspondence: jose.moronesrmr@uanl.edu.mx

${ }^{\dagger}$ Hossein Alishah Aratboni and Nahid Rafiei contributed equally to the work

${ }^{1}$ Facultad de Ciencias Químicas, Universidad Autónoma de Nuevo León, UANL, Av. Universidad s/n, CD. Universitaria, 66451 San Nicolás de los Garza, NL, Mexico

Full list of author information is available at the end of the article population will be higher than 9.8 billion in 2050 if the current population growth rate is maintained [1]. Therefore, within the next 30 years, society will face a series of problems that will put at risk the existence of most living organisms in the planet, and these problems include: energy crisis, global warming, greenhouse effects, toxic gases emission and drastic climate changes. This has created a concern in international scientific communities that seek to tackle one of the main sources of these problems: the use of fossil fuels as our main energy source [2]. One way to counteract the problem, is to seek 
an environmentally-friendly substitute of fossil fuels capable of satisfying the growing global energy demand [3]. Among the alternatives to fossil fuels, biofuels present relevant environmental advantages over the other options [4].

Biofuels are a renewable and sustainable alternative energy source; different regions of the world have used them to partially replace the use of fossil fuels, such is the case of Brazil with sugarcane, Europe and parts of Asia using mostly palm oil as their production source and for the case of biofuels produced from microalgae, countries like Brazil, Japan, China and the Unites States are the leaders in the field. Biofuel production is an important source of job creation, and the first generation of biofuels has allowed significant increments in farmers' incomes [5-7]. These reasons propelled biofuels as a suitable alternative to fossil fuels $[2,8-10]$, especially for the automotive industry, which is one of the activities that generates the largest amounts of carbon dioxide worldwide [11].

Currently, a high percentage of the biofuels produced worldwide come from different raw organic materials, grouped into three different categories or generations $[2,12]$. First-generation biofuels include those based on feedstocks that can be used for human consumption, including crops like maize, sugarcane, palm oil, sugar beet and wheat. Second-generation biofuels are those obtained from lignocellulosic feedstock, the non-edible parts from food crops that are usually discarded such as stems, leaves and husks [13-15]. Although, these generations of biofuels can partially satisfy the global energy demand, they depend on cultivable land available, being its main disadvantage; since cultivable land is limited and the space necessary for their production compete with the production of food crops intended for human consumption. Therefore, biofuels derived from edible or non-edible crops are not considered as the optimal alternative to fossil fuels [16]. A proposed solution to tackle these drawbacks is the third generation of biofuels, obtained from the cultivation of microalgae, unicellular photosynthetic microorganisms capable of converting $\mathrm{CO}_{2}$ and light into biomass and high-energy lipids, precursors of biofuels [17]. Compared with the first two generations of biofuels, the third generation have certain advantageous characteristics: they do not compete with food crop production or available farmland, they require less water, a higher $\mathrm{CO}_{2}$ mitigation rate, the potential to obtain nutrient sources from wastewater, higher carbon uptake and higher lipid content, at least 15-20 times higher than the second generation biofuels obtained from oleaginous crops [18-27]. Microalgae have rapid growth rates in favorable conditions, being able to generate a higher biomass production rate compared with land crops [28]. In addition, the space where microalgae can be cultivated is much smaller, a great advantage over other biofuel alternatives [29], and they are also capable of growing in wastewater or reject water, saline/brackish water and even sewage [30-32]. The use of biofuels obtained from microalgae have the possibility of reducing greenhouse gas effects as they are accountable for $40 \%$ of global carbon fixation and can reach up to $70 \%$ of oil content by dry weight in some strains [4]. Moreover, microalgae as a photosynthetic organism, use water and atmospheric $\mathrm{CO}_{2}$ to convert in a very efficient way, sunlight into chemical energy to produce from the carbon in $\mathrm{CO}_{2}$, valuable organic components such as proteins, carbohydrates and lipids [33, 34].

During the process of photosynthesis, nonpolar lipids like triacylglycerol (TAG), end up being stored in the microalgal cells [33]. It has been widely accepted that the production of these lipids serves as energy storage to microalgae cells. Despite this, they are valuable compounds since have an important commercial value [33, 35-37]. Through the process of trans esterification, the TAGs can be easily converted into fatty acid methyl esters which are an important and versatile form of biodiesel and the cornerstone for its production [2]. The best way to produce high amounts of these lipids is through the efficient large-scale cultivation of microalgae [38]. However, wild-type microalgae under environmental conditions are not capable of producing enough lipids to satisfy the global energy demands. Therefore, different techniques and approaches to enhance higher production rates of lipids in microalgae and make this process sustainable and scalable have been explored [2].

It is important to mention that the production of lipids in microalgal cells goes beyond energy storage since they use these lipids to construct their cellular membranes and are fundamental in the production of other biomolecules [2,39]. Within recent years, researchers have been focused in studying different methods to increase the production of lipids in microalgae cells at different levels (induction with molecules, presence or absence of a factor, and specific growing/production conditions). Here we provide a more comprehensive review of the different lipid induction strategies in microalgae cells and their applications in biofuel production.

\section{Lipids in microalgae}

Lipids produced by microalgae can be divided into two main groups: polar lipids, like glycerophospholipids, which have an important role in cell structure; and nonpolar lipids, like triacylglycerols, mainly responsible for energy storage. Structural lipids (polar lipids) usually have long chains of fatty acids which could be transformed to obtain polyunsaturated fatty acids (PUFAs), this type of fatty acid includes Eicosapentaenoic acid 
(EPA), docosapentaenoic acid (DPA) and docosahexaenoic acid (DHA). PUFAs play an important role in the formation of mitochondrial super complexes [40], they have potential for biofuel production and have been found to have applications in the treatment of some diseases such as atherosclerosis, Parkinson and Alzheimer [41]. Polar lipids and some sterols provide a selectively permeable barrier that protects the cell from the outside and helps in the separation of the different intracellular organelles [42]. These lipids have special roles in the optimal maintenance of membrane fluidity for a variety of metabolic and biosynthetic processes and participate directly in different intracellular membrane fusion events. Moreover, these structural lipids have a significant function in cell signaling pathways and play a key role in response to changes in cellular environment [34, 42].

On the other hand, TAGs play a fundamental role in energy storage within the microalgae cell (Fig. 1), where the photosynthesis process generates basic energy by transforming sunlight into a useful molecule for the cell. To do this, cells use a molecule with a carbon skeleton (Glycerate-3P) and then convert it into more important molecules (such as pyruvate, glucose, xylose, acetate, amino acids, lipids, etc.); this very complex process helps the cell generate the biochemistry which is part of basal and complex metabolism, growth, energy storage and maintenance [43]. Moreover, less than $10 \%$ of these compounds can be metabolized to produce fatty acids in the chloroplast $[44,45]$.

The last product of the fatty acids can be used to produce phosphatidic acid and diacylglycerol in the endoplasmic reticulum (ER) and in the chloroplast, whose participation is known to act at the cellular metabolism level. Due to a variety of conditions and elements, the accumulation of TAGs (specially in situations such as the lack of nutrients or stress environments) can be influenced. Some ER-derived diacylglycerol can be used to assemble TAG in ER [46-49]; these TAGs are principally formed in the light period in ER and stored there, they could be reused for polar lipid constructing in the darkness period [50].

Microalgae cells are constituted of saturated and monounsaturated fatty acids [51]. It was believe that the red algae Porphyridium cruentum was the only one that could accumulate PUFAs in TAGs [52], however, recent studies have discover that some species of green microalgae, such as Parietochloris incisa have better abilities to produce high amounts of omega-6, long-chain PUFA (n-6 LC-PUFA) [53, 54]. Other species, such as Pavlova lutheri, Nannochloropsis oculata, Thalassiosira

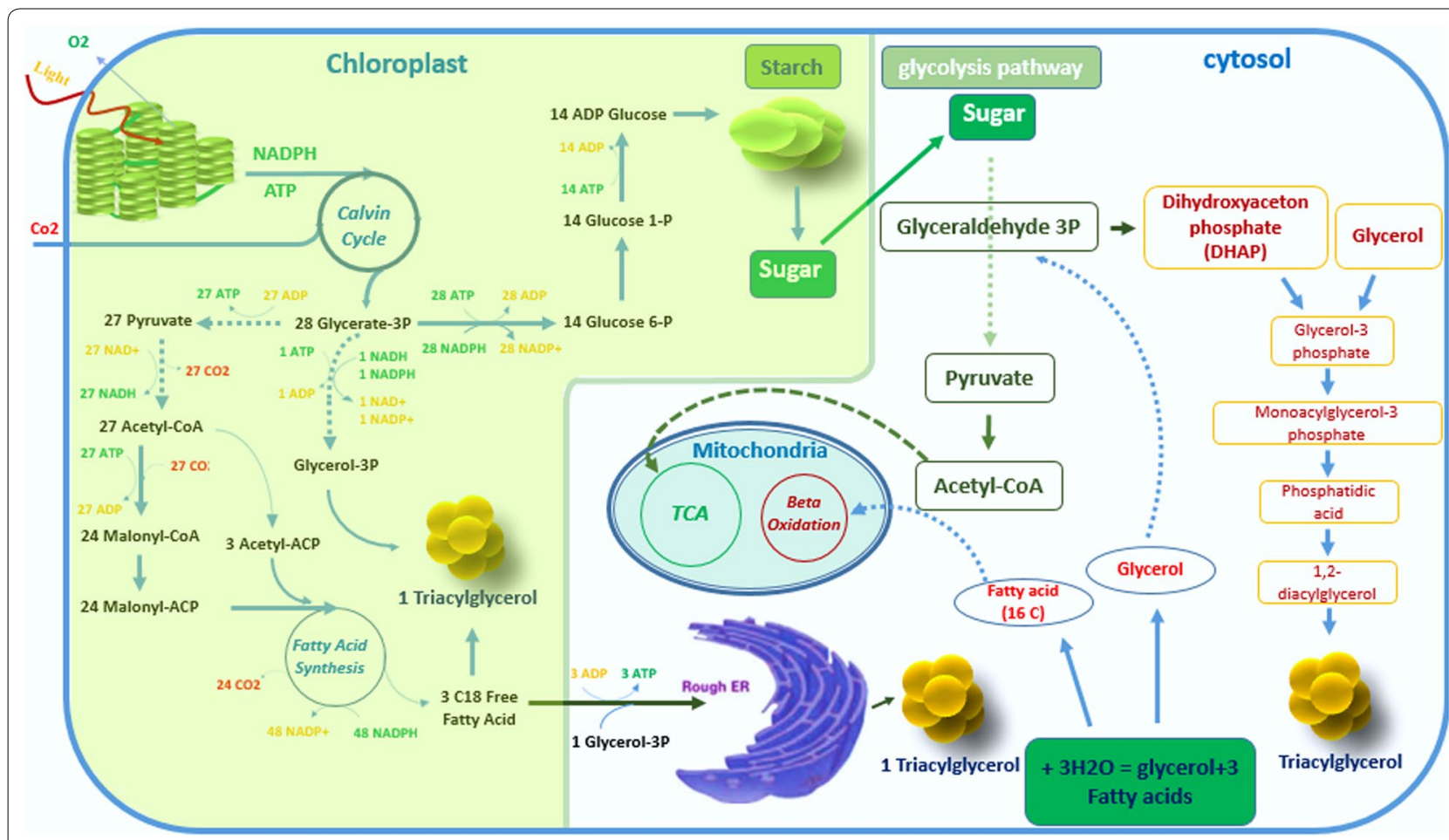

Fig. 1 Simplified photosynthesis process and the three main possible biochemical pathways for TAGs formation: in the chloroplasts, in the ER, or in the cytosol 
pseudonana, and Phaeodactylum tricornutum could also accumulate TAGs but in lower levels $[55,56]$.

Different studies have shown that TAGs can be used to perform more activities besides energy storage activation. For example, they could have an indirect role in the reorganization of membrane in response to a sudden changes in environmental conditions, TAGs can help the production of polar lipids by transferring a special acyl group to cause a rapid adaptive rearrangement of the membrane $[57,58]$.

\section{Approaches to promote lipids production}

Various species of microalgae have different type and quantity of lipids [2] but the basal levels can be altered by modifying lipid metabolism in different ways. A biochemical engineering approach is one method based on the manipulation of the nutritional and/or cultivation conditions. The different cultivation conditions include exposure to different wavelengths and light intensity, carbon dioxide levels, temperature, available nutrients $[27,59]$, stress to heavy metals, stress to salinity $[2,51]$, and the use of nanoparticles (NPs). Other approach is through genetic engineering, where specific genes, related to lipid metabolism, are manipulated to improve synthesis, storage and structural contents of lipids inside the microalgae cell.

\section{Effects of light on lipid production and accumulation}

Light is one of the most important factors for the development of the microalgae and the production of biomass. More importantly, wavelength and light intensity can cause drastic changes on how the microalgae grow and produce/accumulate lipids. Among the different algal species, photoautotrophic species are the only ones that require light to grow, using light as the energy source for their bioprocesses. However, it is important to study other microalgae species such as the photoheterotrophs and the mixotrophs, to improve biomass, especially since around half of the dry weight of the microalgal biomass is carbon, and lipid production $[15,60]$.

Within the literature, there are different studies that report on the effect of different light wavelengths on microalgae growth and metabolism. Some reports confirm the effect of blue $(400-500 \mathrm{~nm})$ and red (600$700 \mathrm{~nm}$ ) wavelengths in the development of microalgae and the optimal performance of key enzymes (structural alteration) in photosynthesis processes and product formation [61]. In these cases, cell pigments play an important role in the absorption of specific light wavelengths, for example, the normal range of the photosynthesis spectrum in microalgae cells is $400 \mathrm{~nm}$ to $700 \mathrm{~nm}$; therefore the pigments inside the cell (mainly chlorophyll a and b) correlate their adsorption spectrum to the optimal conditions of microalgae growth $[62,63]$.

Regarding this, Severes et al. reported that a combination of the wavelengths of red and blue light for the lighting of a culture of Chlorella sp. can cause an increase in the biomass production. Also, they have shown that the dry weight of lipids contained in Chlorella cells is doubled when the wavelength of red light is applied during the growth periods [61]. Similar results were published by Monika and colleagues where they report on the effect of different light wavelengths (light colors: white, red, yellow and green) on the growth behavior and lipid accumulation of a Chlorella sp. strain. According to their results, the best growth and the highest lipid accumulation obtained were when the cells are exposed to red light, meanwhile, the minimum values in these two aspects were obtained with the green light [64].

In another study, a Chlorella vulgaris strain was grown under different internal LED strips of cold white, blue and red, showing that after 10 days with 18:6 light/dark periods, with wastewater as a culture medium and with an initial cell number of approximately $10^{6}$ cells $/ \mathrm{ml}$ they obtained a microalgae cultivated with blue light that reach the highest production of lipid content (34.06\%) due to its efficiency and deep penetration [62]. Meanwhile, Osman et al. discover that the color of the cultivation light affects both the total lipid content and the fatty acid profile; they reported that the saturated fatty acids were not different in the blue, white and green lights, but they were reduced with the red light. The treatment also found that the tendency of the saturated fatty acids was the opposite of the monounsaturated fatty acid [65]. The effect of the light on total oil accumulation and lipid composition correlate with reports presented by Markou [66], Liu et al. [67], Marchetti et al. [68] and Wacker et al. [69].

The light intensity is as important parameter as it has been shown to drastically affect the growth of microalgae and their lipid content. Typically, both low light intensity and extremely high light intensity, causes unfavorable growth and undesirable responses in microalgae cells. In many cases these extreme light intensities cause photoinhibition and photo oxidation that affect lipid content $[2,70]$. Identifying the optimum range of light intensity aids in obtaining the optimal growth of microalgae and a higher lipid production [71, 72]. Many research efforts have been made to show the light intensity needed to obtain the maximum growth and lipid content, but it varies with microalgae species. For instance, Pal et al. report that the microalgae Nannochloropsis sp. produces the highest lipid amount (47\% of dry weight) under a light intensity of $700 \mu \mathrm{mol}$ photons $/ \mathrm{m}^{2} / \mathrm{s}$ [73]. Takeshita et al. showed that C. sorokiniana, C. viscosa, C. emersonii, C. 
vulgaris, P. beijerinckii, and P. kessleri CCALA255, NIES2152, and NIES-2159 can produce more lipids with a light intensity of $600 \mu \mathrm{mol}$ photons $/ \mathrm{m}^{2} / \mathrm{s}$ [74]. Further studies indicate that lipid accumulation in Scenedesmus sp. was increased 11-fold when the intensity of light changes from 250 to $400 \mu \mathrm{mol}$ photons $/ \mathrm{m}^{2} / \mathrm{s}$ [67], while other study demonstrate that the highest lipid accumulation in a Ettlia sp. culture $(291,4 \mathrm{mg} / \mathrm{L} /$ day $)$ is observed at a light intensity of $1500 \mu \mathrm{mol}$ photons $/ \mathrm{m}^{2} / \mathrm{s}$ [75]. Furthermore, lipid content is not affected in several microalgae species when exposed to changes in light intensity; such is the case of Scenedesmus obliquus, where experiments that exposed it to a range of light intensity from 200 to $1500 \mu \mathrm{mol}$ photons $/ \mathrm{m}^{2} / \mathrm{s}$ show that the lipid content remains unchanged [76].

Nowadays, two main categories of microalgae cultivation methods have been suggested. One method involves open systems with configurations of open ponds, tanks, raceway ponds and the other methods involve closed culture configuration systems such as photo bioreactors (PBR) [77, 78]. PBRs are flexible systems that can vary in shape, such as including tubular, vertical columns and flat plates [79]. PBRs have the ability to adjust and have a tighter control in the culture-parameters [80]. Table 1 shows the main advantages and disadvantages of these two types of microalgae cultivation systems [77, 81].

\begin{tabular}{|c|c|c|}
\hline $\begin{array}{l}\text { Cultivation } \\
\text { system }\end{array}$ & Advantages & Disadvantages \\
\hline \multirow[t]{8}{*}{ Open } & Low operating costs & $\begin{array}{l}\text { Process and contamina- } \\
\text { tion controls with low } \\
\text { efficiency }\end{array}$ \\
\hline & Easy to scale up & High evaporation rate \\
\hline & $\begin{array}{l}\text { Cooling through direct contact } \\
\text { with atmosphere }\end{array}$ & $\begin{array}{l}\text { Requires lots of land to } \\
\text { produce }\end{array}$ \\
\hline & Good gas interchange & Poor light penetration \\
\hline & & High loss of $\mathrm{CO}_{2}$ \\
\hline & & High harvesting costs \\
\hline & & $\begin{array}{l}\text { Low production perfor- } \\
\text { mance }\end{array}$ \\
\hline & & $\begin{array}{l}\text { Low control over growth } \\
\text { factors (e.g. evapora- } \\
\text { tion, temperature) }\end{array}$ \\
\hline \multirow[t]{7}{*}{ PBR } & Lower contamination risk & High operating costs \\
\hline & High production performance & High construction cost \\
\hline & Relatively low harvesting cost & Difficult to scale up \\
\hline & High light use efficiency & \\
\hline & Requires low land to produce & \\
\hline & $\begin{array}{l}\text { High control parameters of } \\
\text { culture }\end{array}$ & \\
\hline & Low loss of $\mathrm{CO}_{2}$ & \\
\hline
\end{tabular}
pond and closed culture systems for microalgae biomass production

Both open and PBR cultivation systems are used in large-scale commercial production of biomass to obtain different chemical compounds, such as fatty acids, proteins, anti-oxidants, pigments and animal feedstock [82]. Nevertheless, considering the sensitivity of the open pond system to contamination, the open pond systems is mainly used for biomass production of microalgae strains, which grow in specific conditions, such as high nutrient concentration. Jorquera et al. introduced Chlorella sp., Spirulina sp. and Dunaliella salina as strains with a requirement of specific growth condition [83]. Hence, it is indispensable to employ PBRs to produce high-value products such as human nutrient and pharmaceutical products from microalgae which are grown under tightly controlled conditions [84].

One aspect to be considered is the difficulty of controlling light exposure in an industrial production setting. One main design aspect of culture systems involves the ratio between light exposure surface area and volume of culture. The literature shows that typically high ratios between these two parameters lead to higher biomass yields and growth in microalgae. Therefore there is an intense area or research being developed to design innovative culture systems with the purpose of maximizing light exposure area per volume of culture. Although both open pond and closed PBRs can use either natural sunlight or artificial illumination for microalgae cultivation [85], closed PBRs offer better control of light than open systems. Controlling wavelength and intensity of light is more feasible in a lab-scale PBRs compared to industrial settings. Therefore, optimal conditions are determined in a lab-scale PBR to further test large-scale models. One of the complexities in the scalability of these systems is correlating light permeation into the cultures system since it decreases exponentially with distance from the light source, posing a difficult engineering problem when scaling PBR systems [86, 87].

Contrary to closed PBRs, surface-to-volume ratio and the corresponding light penetration in open ponds system are far from ideal; although direct sunlight is too strong for most microalgae, most of them only need $1 / 10$ of direct sunlight [88]. Mainly, in most open pond system, only the top 7-10 $\mathrm{cm}$ of water are exposed to enough light penetration for efficient photosynthesis [89], the causes are bulk algal biomass that is accumulated in the surface which leads to blocking natural light sources and preventing it from reaching deeper into the water [90]. However, one main advantage of open culture systems is that they are inexpensive to install and operate [87].

When comparing both open and closed systems, choosing between them heavily depends on specific conditions of the user, however, it should be clear that for research and in order to expand understanding the 
behavior of a microalgae culture, the most convenient way is through PBRs. In this regard, a simulation model for algae production in greenhouses system, developed by Hermans et al. [91] and then adopted in industrial settings, was used to calculate the yearly algae production in a one-hectare greenhouse filled with PBRs in the Netherlands [92]. Their study showed that the minimum cost price of algae produced in a one-phase and two-phase tubular PBR were between 16-35 $€$ and 11-19 $€$ per kg of dry algae biomass, respectively. Very interestingly the report included depreciation of the PBR and greenhouse equipment, labor, maintenance and electricity required for illumination, this last one accounting for the highest percentage of the total cost.

\section{Carbon dioxide}

The atmosphere, industries discharge gases and carbonate salts are highly valuable sources for microalgae cultures and other photosynthetic microorganisms, to capture $\mathrm{CO}_{2}$ and in the presence of sunlight use the inorganic carbon to produce biomass and chemical compounds of interest [93] (Table 2). For microalgae to grow and be metabolically active, there are specific maximum and minimum $\mathrm{CO}_{2}$ level parameters that must be reached. These optimal $\mathrm{CO}_{2}$ levels influence lipid production and their accumulation within the cell [2]. Although the increase of $\mathrm{CO}_{2}$ could help in the production and accumulation of lipids in the microalgae cells, as mentioned previously there is also a maximum level where the excess $\mathrm{CO}_{2}$ levels leads to disruptive effects in lipid production and cell growth. Previously it was believed that the microalgae cells develop best at high concentrations of $\mathrm{CO}_{2}$ and this was corroborated with experiments performed with some species of Nannochloropsis, which are not inhibited at high $\mathrm{CO}_{2}$ levels. However, later experiments have demonstrated that most species exhibit a maximum range where $\mathrm{CO}_{2}$ become non-optimal and in some cases lethal to the culturing of microalgae [94-96].

When a culture of microalgae cells is aerated with high concentrations of $\mathrm{CO}_{2}$, a part of the carbon is used by the cells for the process of photosynthesis, but the remaining carbon could be converted to carbonic acid $\left(\mathrm{H}_{2} \mathrm{CO}_{3}\right)$. This compound can cause acidification of the medium, altering cell growth and metabolic pathways. Ying et al. studied $\mathrm{pH}$ changes in the medium when exposing the culture to different $\mathrm{CO}_{2}$ aeration parameters, and they report that dramatic $\mathrm{pH}$ changes that lead to damage of enzymes involved in the photosynthesis process. Hence, it is very important to consider optimum $\mathrm{pH}$ levels for the various species of microalgae to determine the $\mathrm{CO}_{2}$ exposure optimal for biomass growth and lipid production and accumulation in the cells [97].

A variety of works in the literature have focused on understanding the effect of different $\mathrm{CO}_{2}$ concentrations on microalgae cells. Montoya et al. determined a high concentration of fatty acids and lipid productivity $(29.5 \mathrm{mg} / \mathrm{L} /$ day $)$ in a culture of C. vulgaris with a $\mathrm{CO}_{2}$ concentration of $8 \%(\mathrm{v} / \mathrm{v})$ [107]. In another work, Ying et al. reported an inhibition of growth in a culture of $D$. Salina with a $0.02 \mathrm{~mol} \mathrm{CO}_{2} / \mathrm{L}$ concentration and discover that if the concentration increases more than $0.02 \mathrm{~mol}$ $\mathrm{CO}_{2} / \mathrm{L}$ (i.e. constant doses of $50 \%(\mathrm{v} / \mathrm{v}) \mathrm{CO}_{2}$ ) it turned out to be deadly for its growth [97]. Moreover, Chlorella Pyrenoidosa an oleaginous specie, was cultivated under 5\% (v/v) of $\mathrm{CO}_{2}$ concentration, obtaining the highest lipid productivity, $107 \mathrm{mg} / \mathrm{L} /$ day. Bagchi and Mallick reported that a cultivated Scenedesmus Obliquus (Turpin) Kützing

Table 2 Studies on the effect of $\mathrm{CO}_{2}$ levels on the accumulation of lipids in different species of microalgae

\begin{tabular}{|c|c|c|c|}
\hline Microalgae strain & Used $\mathrm{CO}_{2}$ concentration & Change of lipid amount & Refs. \\
\hline Chlorella sp. BTA 9031 & $3 \%(v / v)$ & Accumulated $25 \%$ of lipid as a percentage of dry cell weight & [98] \\
\hline Chlamydomonas sp. JSC4 & $4 \%(v / v)$ & Generated maximum lipid content (65.3\%) and productivity (169.1 mg/L/day) & {$[99]$} \\
\hline Chlorococcum littorale & $5 \%(\mathrm{~V} / \mathrm{V})$ & Lipid content increased up to $34 \%$ wt & {$[100]$} \\
\hline Scenedesmus obliquus CNW-N & $\begin{array}{l}\text { The optimal CO2 consump- } \\
\text { tion rate was } 1420.6 \mathrm{mg} / \mathrm{L} / \\
\text { day }\end{array}$ & The highest productivity of lipid (140.35 mg/L/day) is achieved & {$[101]$} \\
\hline Synechocystis sp. PCC6803 & $3 \%(v / v)$ & The total lipid content increased up to 14\% of dry weight & {$[102]$} \\
\hline Porosira glacialis & $20-25 \%$ levels of $\mathrm{CO}_{2}$ & $\begin{array}{l}\text { The total lipid content increased from } 8.91 \text { to } 10.57 \% \text { in cell dry mass } \\
\text { Docosahexaenoic acid content increased from } 3.90 \text { to } 5.75 \% \\
\text { EPA decreased from } 26.59 \text { to } 23.66 \%\end{array}$ & {$[103]$} \\
\hline Attheya longicornis & $20-25 \%$ levels of $\mathrm{CO}_{2}$ & Did not show any significant increase in total lipid content & {$[103]$} \\
\hline Nannochloropsis oculata & $3 \%(v / v)$ & Demonstrated high lipid content (53.2 wt\%) & {$[104]$} \\
\hline Scenedesmus sp. & $10 \% \mathrm{CO}_{2}$ & Lipid productivity reached up to 20.65 mg/L/day & {$[105]$} \\
\hline Chlorella vulgaris & $30 \% \mathrm{CO}_{2}$ & $\begin{array}{l}\text { The highest lipid content ( } 45.68 \%) \text { and lipid productivity ( } 86.03 \text { mg/L/day) is } \\
\text { obtained }\end{array}$ & {$[106]$} \\
\hline
\end{tabular}


GA 45 with $15 \%(\mathrm{v} / \mathrm{v})$ of $\mathrm{CO}_{2}$ concentration was able to obtain a lipid accumulation performance of $850 \mathrm{mg} / \mathrm{L}$ in a period of 16 days [108]. Finally, green microalgae of the Chlamydomonas sp. JSC4 strain were cultured under $4 \%(\mathrm{v} / \mathrm{v}) \mathrm{CO}_{2}$ achieving a maximum lipid productivity (169.1 mg/L/day) [99].

\section{Temperature}

Temperature is another important factor that affects growth and the lipid content in microalgae cells. Different studies have shown that temperature changes have a crucial effect on microalgae development, lipid production and formation of fatty acids, however optimal parameters depend on the species. The literature shows that the biochemical pathways related to the synthesis and accumulation of lipids are controlled by enzymes with a high sensitivity to thermal variations [109]. Some researches based on reported results suggest that as the temperature increases, microalgae tend to produce and accumulate saturated fatty acids; opposite to this, at low temperatures microalgae tend to produce and accumulate unsaturated fatty acids. Menegol et al. studied the effects of temperature on Heterochlorella luteoviridis, finding that with a temperature set at $22{ }^{\circ} \mathrm{C}$, it could get a $40.7 \%$ of PUFAs (of the total percentage of fatty acids), and when the temperature change from 22 to $27^{\circ} \mathrm{C}$, the percentage of saturated fatty acids was increased (52.9\%) [110].

Depending on the objective of the study, the ideal temperature for microalgae cultivation can be selected, but as with the other parameters, the optimal temperature will vary for each species of microalgae affecting significantly their growth and lipid production. Such is the case observed with Nannochloropsis limnetica, where the cells can grow in the range of $15{ }^{\circ} \mathrm{C}$ to $27{ }^{\circ} \mathrm{C}$ but their maximum growth and lipid productivity occurs at $22{ }^{\circ} \mathrm{C}$ [111]. Converti et al. have studied $N$. oculata and C. vulgaris, they suggest that an increase in temperature causes a decrease in lipid content in C. vulgaris, and the decrease causes an increase of lipid content. Meanwhile, in N. oculata, increase and decrease temperature resulted in increase and decrease of lipid production, respectively [112].

Two strains of Monoraphidium consortiums and Desmodesmus quadricauda showed that a decrease in temperature of up to $13{ }^{\circ} \mathrm{C}$ provides an optimal condition for lipid accumulation [113]. In a different study, the optimal temperature for Tetraselmis subcordiformis and $N$. oculata was $20^{\circ} \mathrm{C}$ and $30^{\circ} \mathrm{C}$, respectively [114]. In addition, considering that there are open and closed systems, regulation for high and low temperatures can only be carried out in closed PBRs, since open systems are typically operated at environmental conditions with constantly varying temperature [51]. Temperature is a very important condition that should be considered in the cultivation of microalgae, a closed system is an excellent method for temperature control, especially when an optimal temperature has been determined to obtain the best lipid productivity and biomass quantity.

\section{Nutrient limitation}

Essential inorganic nutrients such as nitrogen, sulfur, carbon, iron and phosphorus have remarkable impact on growth, reproduction and metabolism of microalgae cells. Nutrient limitation is an applied and promising strategy used by many researchers to change and control the microalgae cell cycle and the biochemical pathways linked to lipid production and accumulation. The lack of nutrients causes undesirable situations inside the cell, generating the accumulation of more lipid compounds as a response, this technique has been therefore exploited by researchers and the industry to increase lipid production and accumulation [115].

In a culture medium, cell growth is linked to availability of a high concentration of nutrients in the culture, especially during the early life cycle stages of cell growth; a rich media therefore leads to a maximization of biomass productivity. Then, after reaching the necessary biomass, nutrient limitation can cause an environment of stress and a ramp-up in lipid production, especially observed in the late growth-stages. Most of the work and studies have shown that numerous species of microalgae produce and accumulate higher amount of lipids, specially the TAGs, in nitrogen-limited mixotrophic conditions [116-119]. However, it is possible that nutrient limitation might affect other biochemical pathways in the cells impacting indirectly lipid productivity [120].

Several studies have explored different nutrient limitation techniques in different strains to understand and optimize different output parameters. Yang et al. showed that under situations of phosphorus or nitrogen deficiency the fatty acid yield in Chlamydomonas reinhardtii is significantly increased [121]. Cordeiro et al. carried out a study of the effects of phosphorus and nitrogen levels on the growth of species of Microcystis, they reported that the obtained lipid performance from Microcystis panniformis and Microcystis novacekii had the inverse and direct correlation with nitrogen (35.8\%) and phosphorus concentration (31.7\%), respectively. They also have reported that Microcystis aeruginosa had an inverse correlation with the nutrient concentration (23.3\%) [122]. Furthermore, Mata et al. showed that by increasing ten times the concentration of nitrogen in the culture medium, lipid productivity and content increased $33.5 \%$ and $47.4 \mathrm{mg} / \mathrm{L} /$ day, respectively in Dunaliella tertiolecta [123]. It was also shown that by increasing the 
iron concentration 10 times (compared to the standard culture medium), the lipid productivity increased from $14.6 \mathrm{mg} / \mathrm{L} /$ day to $28.0 \mathrm{mg} / \mathrm{L} /$ day. Finally, Figueroa et al. cultivated C. reinhardtii under limited mixotrophic conditions, and had a significant $66 \%$ increase in lipid production $(0.08 \mathrm{~g} / \mathrm{L})$.

\section{Heavy metal stress}

There are some heavy metals such as $\mathrm{Cu}, \mathrm{Fe}, \mathrm{Mn}, \mathrm{Ni}$ and $\mathrm{Zn}$ that are vital micronutrients in many biological processes [124-126] since they have essential roles as precursors of vitamins, catalytic cofactors for numerous metallo-enzymes, and structure proteins of the cell membrane $[124,127,128]$.

Microalgae have proven to be efficient and effective in the removal of heavy metals and are able to tolerate high concentrations of heavy metals through different mechanisms such as coupling metals to surface proteins, expression of cellular ligands to create metal complexes, triggering of efflux pumps to excrete metal ions, and kidnapping heavy metals through polyphosphates, phytochelatins and metallothioneins [129]. The accumulation of high concentrations of heavy metals can cause the production of reactive oxygen species (ROS) [130], inhibition in the synthesis of chlorophyll [131] and negative disruption on cell proliferation [132] affecting lipid accumulation within the microalgae cell [133]. In different studies, heavy metal stress has led to increase the lipid content in some microalgae [134].

Ren et al. evaluated the effects of $\mathrm{Fe}^{3+}(0-0.12 \mathrm{~g} / \mathrm{L})$, $\mathrm{Mg}^{2+}(0-0.73 \mathrm{~g} / \mathrm{L})$ and $\mathrm{Ca}^{2+}(0-0.98 \mathrm{~g} / \mathrm{L})$ on lipid accumulation in Scenedesmus sp. cells and suggested that the total lipid content and lipid productivity increased up to $28.2 \%$ and $29.7 \%$, respectively with the addition of EDTA during cultivation [133]; this implies that, the main metabolic pathways related to lipid synthesis and breakdown in Scenedesmus sp. cells could be modified by $\mathrm{Fe}^{3+}, \mathrm{Mg}^{2+}$ and $\mathrm{Ca}^{2+}$ [135]. These metal ions have multiple physiological functions that affect metabolic activity of microalgae cells and their lipid accumulation processes [136], for example, $\mathrm{Ca}^{2+}$ is a universal messenger involved in the signaling of environmental and developmental stimuli [137]. It is worth noting that $\mathrm{Mg}^{2+}$ has been recognized as an important signaling ion, both activating and mediating many biochemical reactions, such as regulation of carbon fixation in chloroplasts in the Calvin cycle [138, 139]. In addition, the literature shows that the increment of

$\mathrm{Mg}^{2+}$ could assist Acetyl-CoA carboxylase (key regulator of fatty acid synthesis) function to increase the neutral lipid content in microalgae cells [136]. Battah et al. examined the effect of heavy metals $\left(\mathrm{Mn}^{2+}\right.$ and $\left.\mathrm{Co}^{2+}\right)$ on the lipid content of C. vulgaris [140], using manganese chloride $\left(\mathrm{MnCl}_{2}\right)$ at a concentration of $2 \mu \mathrm{M}, 10 \mu \mathrm{M}$ and $12 \mu \mathrm{M}$. The results demonstrate that all of these concentrations increased lipid content significantly by $14 \%, 16 \%$ and $15 \%$, respectively. They also discovered that if cobalt nitrate is added at different concentrations, lipid content can be increased up to $25 \%$ more, compared to the corresponding controls.

An additional study reports up to $56.6 \%$ increase in the total lipid content in C. vulgaris at 5 different $\mathrm{Fe}^{3+}$ concentrations in the culture medium [135]. Einicker-Lamas et al. mentioned that cadmium increases the total lipid content in Euglena gracilis. For the case of cadmium and its effects on C. vulgaris, reports have shown that TAGs, acetone mobile polar lipids (AMPL) and phospholipids (PL) were the main lipid classes after exposing C. vulgaris to different combinations of cadmium $\left(2 \times 10^{-8} ; 10^{-7} \mathrm{M}\right)$ and nitrogen $\left(2.9 \times 10^{-6}\right.$ to $\left.1.1 \times 10^{-3} \mathrm{M}\right)$ Furthermore, by changing the combination of nitrogen and cadmium in the medium it is possible to alter and control lipid composition [134].

\section{Nanoparticles}

Researches have used various types of metallic NPs, within a range of 5-100 $\mathrm{nm}$, since they exhibit different physical and chemical properties than the same metals at the macroscale $[109,141]$. The diverse physicochemical behavior of metallic nanoparticles have allowed their use for many different applications in drug delivery systems, the food industry, cosmetics, optics and the synthesis of multifunctional biomaterials [142]. One very recent application of NPs is linked to their ability to improve gas-liquid mass transfer rate in fermentations $[143,144]$. The presence of the NPs improves the mass transfer coefficient at the gas-liquid interface [145]; therefore, the assumption is that the increase of $\mathrm{CO}_{2}$ concentrations through NPs can affect the growth rate and the induction of lipids in some microalgae.

Jeon et al. used silica nanoparticles and methylfunctionalized silica $\left(\mathrm{SiO}_{2}-\mathrm{CH}_{3}\right)$ nanoparticles in a $C$. vulgaris culture. They used Blue-Green medium (BG11) and grew microalgae that used solely $\mathrm{CO}_{2}$ as a carbon source; they were able to observe that the NPs increased the gas-liquid mass transfer rate in this $\mathrm{CO}_{2} /$ medium culture system and improved both growth and lipid accumulation in the cultivated microalgae. They reported that the use of both NPs causes an increase in the volumetric mass transfer coefficient $\left(\mathrm{k}_{\mathrm{L}} \mathrm{a}\right)$ of $31 \%$ and $145 \%$, respectively; the results also showed that, although the addition of silicon NPs leads to an increase in cellular dry weight and in fatty acid methyl ester productivity, the highest cellular dry weight $(1.49 \mathrm{~g} / \mathrm{L})$ and the highest fatty acid methyl ester productivity $(610 \%)$ 
were obtained by the addition of $0.2 \mathrm{wt} \% \mathrm{SiO}_{2}-\mathrm{CH}_{3}$ NPs [146].

Similarly, Ahn et al. examined the effect of magnetic cobalt ferrite/silica NPs and methyl functionalized magnetic silica NPs (methyl-MSNs) on growth and lipid production in a culture of $C$. vulgaris by improving gaswater mass transfer and increasing the concentration of dissolved $\mathrm{CO}_{2}$. Reporting that for the $\mathrm{k}_{\mathrm{L}} \mathrm{a}$ of $0.3 \mathrm{wt} \%$ of the MSNs and methyl-MSNs were $3.11 / \mathrm{h}$ and $4.01 / \mathrm{h}$, respectively; and the use of $0.3 \mathrm{wt} \%$ Methyl-MSNs yielded the highest mass transfer rate [147]. Nonetheless, improving the rate of mass transfer not only does not increase the lipid content, but also decreases it sharply (to $3.37 \%$ and $4.57 \%$, respectively).

It has been found that some metallic NPs such as Ag, $\mathrm{Au}, \mathrm{CuO}, \mathrm{ZnO}, \mathrm{Se}, \mathrm{Pd}$ and $\mathrm{FeO}$ turn out to be highly toxic for different organisms [148-153]. One of these affected organisms is microalgae (Table 3); the toxic effect of NPs is related to ROS production and the induction of oxidative stress, this is only achieved when the concentration of NPs reaches an effective level [149-151].

Some researchers mention that if microalgae are exposed to adequate doses of NPs, they can induce oxidative stress and thus improve lipid production [142, 160, 161]. He et al. evaluated the effects of Carbon nanotubes (CNTs), $\alpha-\mathrm{Fe}_{2} \mathrm{O}_{3} \mathrm{NPs}$ and MgO NPs on lipid production of Scenedesmus obliquus, and they discovered that exposure to $5 \mathrm{mg} / \mathrm{L} \mathrm{CNTs}, 5 \mathrm{mg} / \mathrm{L} \mathrm{Fe}_{2} \mathrm{O}_{3}$ and $40 \mathrm{mg} / \mathrm{L} \mathrm{MgO}$ NPs increased the lipid content up to $8.9 \%, 39.6 \%$ and $18.5 \%$, respectively. In addition, when microalgae were exposed to high doses of NPs, biomass and lipid production decreased, due to the high concentrations of ROS generated that caused cell death [142].
Similarly, Kang et al. used the oxidative stress of $\mathrm{TiO}_{2}$ NPs to stimulate and enhance lipid productivity in $C$. vulgaris UTEX 265 and suggested that oxidative stress causes the accumulation and decomposition of lipid productivity. They also mention that the highest productivity of fatty acid methyl ester $(18.2 \mathrm{~g} / \mathrm{L} /$ day $)$ was obtained with low doses of $\mathrm{TiO}_{2} \mathrm{NPs}(0.1 \mathrm{~g} / \mathrm{L})$ and a short induction time of 2 days [160].

Other reports related to the use of NPs to improve lipid productivity are listed in Table 4 . It should be emphasized that the use of NPs for the improvement of lipid productivity is a unique method and has some disadvantages for example, how expensive it is to recycle NPs for the following experiments. Therefore, more in depth studies should be carried out to describe in detail the stability and environmental effects that NPs can cause.

\section{Saline stress}

Salts play a vital role in the physiological and bio-chemical pathways of growth, reproduction and metabolism of fatty acids in microalgae, therefore, saline stress is one of the most efficient enrichment strategies for lipid content. Because of this, many researchers have focused on studying salt stress for this purpose [167-169].

Saline stress is known to cause a difference in osmotic pressure within microalgae cells, which, generates a stress-response that leads to the modification of their metabolism which will allow the microalgae to adapt to these new conditions [170, 171]. Changes at the metabolic level causes saline fluctuations within the cell, increasing significantly the lipid content; it has even been found that variations in the concentration of salt in the growth medium not only increase the total lipids of the

Table 3 Toxic effect of different NPs in several species of microalgae

\begin{tabular}{|c|c|c|c|c|}
\hline Microalgae strain & Type of NPs & Size of NPs & Used concentration & Refs. \\
\hline $\begin{array}{l}\text { Platymonas subcordiforus } \\
\text { Chaetoceros curvisetus } \\
\text { Skeletonema costatum }\end{array}$ & CoNPS & $30 \mathrm{~nm}$ & $\begin{array}{l}67.2 \mathrm{mg} / \mathrm{L} \\
38.6 \mathrm{mg} / \mathrm{L} \\
21.5 \mathrm{mg} / \mathrm{L}\end{array}$ & {$[154]$} \\
\hline Soil alga Chlamydomonas reinhardtii & Ag NPs & $<100 \mathrm{~nm}$ & 0-50 mg Ag NPs/kg dry weight soil & {$[155]$} \\
\hline $\begin{array}{l}\text { Chlorococcum sp. } \\
\text { Scenedesmus rubescens } \\
\text { Dunaliella tertiolecta } \\
\text { Tetraselmis suesica }\end{array}$ & $\mathrm{ZnONPs}$ & $<100 \mathrm{~nm}$ & $0.081-810 \mathrm{mg} / \mathrm{L}$ & {$[156]$} \\
\hline $\begin{array}{l}\text { Navicula sp. } \\
\text { Chetoceros sp. }\end{array}$ & CoONPs & $<50 \mathrm{~nm}$ & $2 \mathrm{mg} / \mathrm{ml}$ & {$[1]$} \\
\hline Dunaliella salina & $\mathrm{SiO}_{2} \mathrm{NPS}$ & $11-14$ & $0.1,0.3,0.85,2.4,7,20$ and $50 \mathrm{mg} / \mathrm{L}$ & {$[157]$} \\
\hline Chlorella vulgaris (KCTCAG10002) & $\begin{array}{l}\mathrm{ZnO} N P s \\
\mathrm{CuO} N P s \\
\mathrm{NiO} \mathrm{NPS} \\
\mathrm{TiO}_{2} \mathrm{NPS} \\
\mathrm{Fe}_{2} \mathrm{O}_{3} \mathrm{NPS}\end{array}$ & $\begin{array}{l}40-100 \mathrm{~nm} \\
30-50 \mathrm{~nm} \\
30 \mathrm{~nm} \\
<25 \mathrm{~nm} \\
20-40 \mathrm{~nm}\end{array}$ & $\begin{array}{l}8,16,33 \mathrm{mg} / \mathrm{L} \\
0.5,1,2 \mathrm{mg} / \mathrm{L} \\
4,9,18 \mathrm{mg} / \mathrm{L} \\
20,40,80 \mathrm{mg} / \mathrm{L} \\
22,45,90 \mathrm{mg} / \mathrm{L}\end{array}$ & {$[158]$} \\
\hline Dunaliella salina & $\mathrm{Al}_{2} \mathrm{O}_{3} \mathrm{NPS}$ & $20 \mathrm{~nm}$ & $0.005,0.026,0.14,0.7$, and $3.8 \mathrm{mg} / \mathrm{L}$ & {$[159]$} \\
\hline
\end{tabular}


Table 4 Improvement of lipid productivity using different types of NPs in some species of microalgae

\begin{tabular}{|c|c|c|c|c|}
\hline Microalgae strain & Type of NPs & Utilization & Lipid profile change & Refs. \\
\hline \multirow[t]{4}{*}{ Chlorella vulgaris } & CuNPs & Metal resistance induction & Total lipid increase (up to 32\%) & [162] \\
\hline & Mg NPs & Photosynthesis enhancement & Lipid content increase (0.43 mg/L) & \\
\hline & Zn NPS & Metal resistance induction & Total lipid content increase (0.74 mg/L) & \\
\hline & $\mathrm{Pb} N \mathrm{NS}$ & Increase of growth rate & Total lipid content increase (0.76 mg/L) & \\
\hline Isochrysis galbana & Fe NPs & - & No significant difference in total lipid content & {$[163]$} \\
\hline Pavlova lutheri & & Increase of growth rate & Increase of the total lipid (up to 12 pg/cell) & \\
\hline Tetraselmis suecica & & Increase of growth rate & Increase of the total lipid (up to 40 pg/cell) & \\
\hline Chlorella vulgaris & Nanoscale MgSO4 & Photosynthesis enhancement & $\begin{array}{l}185.29 \pm 4.53 \% \text { improvement in lipid produc- } \\
\text { tion }\end{array}$ & {$[164]$} \\
\hline Chlorella sp. KR-1 & CTAB-decorated Fe3O4 NPs & $\begin{array}{l}\text { Improvement of harvesting and cell } \\
\text { disruption efficiency }\end{array}$ & $\begin{array}{l}\text { The cells harvested using CTAB-OTES-MNP } \\
\text { yielded an approximately 2.3-fold-higher } \\
\text { lipid content compared with the control } \\
\text { extracted by only hexane }\end{array}$ & {$[165]$} \\
\hline Nannochloropsis maritima & Fe3O4 NPs & Improvement of harvesting efficiency & $\begin{array}{l}\text { The algal biomass increased up to } 1.02 \mathrm{~g} / \mathrm{L} \\
\text { at day } 18 \text { (subsequently, more total lipid } \\
\text { amount is achieved) }\end{array}$ & {$[166]$} \\
\hline
\end{tabular}

microalgae cells, but can also altered lipid composition [51].

Bartley et al. investigated the effects of salt stress on the growth of marine microalgae Nannochloropsis salina. They grew it at 22 PSU (particle salinity unit) until the culture reaches the stationary phase and then they increased the concentration of salts to 34,46 , and 58 PSU. They reported that the lipid content increased significantly under these salt concentrations, obtaining the highest total content of fatty acids (36\% dry tissue mass) at 34 PSU [172].

Meanwhile in a study by Salama et al, Chlamydomonas Mexicana and Scenedesmus obliquus were grown in a culture medium with different levels of salt stress reaching up to $100 \mathrm{mM} \mathrm{NaCl}$; showing that the maximum lipid content obtained (37\% and $34 \%$ respectively) from $C$. Mexicana and S. obliquus were achieved with a concentration of $25 \mathrm{mM} \mathrm{NaCl}$. They also investigated the composition of fatty acids, finding that linoleic acids (41\%) and oleic acids (41\%) were the dominant fractions. Although the data on the effect of $\mathrm{NaCl}$ on the fatty acid composition of microalgae lipids are scarce and conflicting, these results also show that the higher concentrations of $\mathrm{NaCl}$ in some species of microalgae such as Chlamydomonas Mexicana and Scenedesmus obliquus can improve the composition of their fatty acids [173]. Depending on the type of lipid used, different levels of $\mathrm{NaCl}$ can be used to alter the fatty acid composition. In other words, depending on which one of polyunsaturated fatty acids, monounsaturated fatty acids and saturated fatty acids are needed, the suitable $\mathrm{NaCl}$ level can be used.

Pandit et al. grew two strains of microalgae (C. vulgaris and Acutodesmus obliquus) in a medium that contained different levels of salt concentration (from 0.06 to $0.4 \mathrm{M}$
$\mathrm{NaCl}$ ) and they reported that the maximum amount of lipids ( $49 \%$ and $43 \%$, respectively) was obtained at a concentration of $0.4 \mathrm{M} \mathrm{NaCl}$ [174]. Besides, Acutodesmus dimorphus showed a significant accumulation of lipids $(33.40 \pm 2.29 \%)$ in $200 \mathrm{mM} \mathrm{NaCl}$ of added medium; and the lipid accumulation increased significantly up to $43 \%$, when saline stress extended to 3 days [175].

The type of salt used to cause the saline stress also has an effect on the accumulation of lipids in microalgae. Srivastava et al. cultivated Chlorella sorokiniana CG12(KR905186) and Desmodesmus GS12(KR905187) with different types of salts $\left(\mathrm{NaCl}, \mathrm{KCl}, \mathrm{MgCl}_{2}\right.$ and $\mathrm{CaCl}_{2}$ ) and found that with $\mathrm{CaCl}_{2}$ the maximum effect on lipid production was obtained, improving up to a $40.02 \%$ and $44.97 \%$ in CG12 and GS12, respectively. It is assumed that $\mathrm{Ca}^{2+}$ plays a definitive role in cell signaling under conditions of salt stress which causes an increase in the synthesis of lipid compounds [176].

\section{Genetic modification of microalgae to increase lipid production}

Employing molecular biology to genetically alter microalgae is an approach that offers an alternative to obtain better lipid productivity. Recently, different genetic engineering methods have received a lot of attention from researchers because they are considered novel and especially tunable tools $[177,178]$. In general, it seeks to reduce, inhibit or over express one or several genes related to the production of a metabolite of interest. For the case of the microalgae, these genes are related with the photosynthetic process, the growth rate, improved resistance against extreme conditions such as $\mathrm{pH}$, salinity, temperature and genes that have great importance in the metabolism of lipids [109]. The impact on the 
microalgae are related to: fast growth and large cell size for high biomass production, high lipid yield, the ability to secret lipid into media, adaptive capability to environmental fluctuations and stress and the ability to form flocs for easy and low-cost harvesting [194].

However, one of the main limitations of this approach relies on the data available to do such modifications; sequencing the genomes of microalgae and having them available facilitates genetic manipulation, allowing to know with greater detail and precision the different genes that participate in the different metabolic pathways. Several nuclear microalgae genomes have been sequenced (C. reinhardtii, P. tricornutum, T. pseudonana, Cyanidioschyzon merolae, Ostreococcus lucimarinus, Ostreococcus tauri, and Micromonas pusilla). However there are a lot of ongoing projects to have more genomes available $[181,184]$. Despite this, it is estimated that there are 72.500 species of microalgae but only about 44.000 have been described [186].

For genetic modification of microalgae there are a variety of bioengineering methods that can be applied: Random Mutagenesis, Clustered Regularly Interspaced Short Palindromic Repeats-CRISPR associated with the protein 9 (CRISPR-Cas9), Transcription Activator-Like Effector Nucleases (TALEN) and Zinc-Finger Nucleases (ZFN) used mainly for the alteration of the gene sequence [179-181]; while the use of micro RNA (miRNA), short interfering RNA (siRNA) and homologous recombination allows the activation and repression of genetic expression [182-184]; meanwhile agitation in the presence of glass bread or silicon, carbide whiskers, electroporation, biolistic microparticle bombardment and Agrobacterium tumefaciens-mediated gene transfer has been used to transfer DNA into microalgal cells [4, 181]. The efficiency of transformation strongly depends on the microalgae specie and both the genetic modification method and the transformation method must to be carefully selected according to the specie and type of modification.

The use of the CRISPR-Cas9 system allows the regulation of the expression of multiple target genes [185], the expression of complex traits through the multigene engineering. Since 2014, the use of this tool marked a beginning of a new age of genome editing in microalgae; although the main challenge of using this tool is the toxicity of the Cas9 nuclease (with a mutation rate of $10 \%$ ); which has an alternative, the use of ribonucleoproteins $[4,188,189]$.

The majority of the genetic edition reports on microalgae for the increase of lipid production have been carried out in the study models as Chlamydomonas and Chlorella [186]. The earliest successful DNA modification was accomplished by Rochaix and Van Dillewijin in
C. reinhadtii $[4,187]$. And in the case of fatty acid biosynthesis, Roessler isolate the acetyl-CoA carboxylase in 1990 to later transform the diatoms Cyclotella cryptica and Navicula saprophila [51, 193].

One of the first experimental reports related to this was done by Dunahay and colleagues when they tried to introduce additional copies of the acetyl-CoA carboxylase gene in the diatom Cyclotella cryptica to manipulate the lipid accumulation [187]. Kang et al. investigated the gene of a Wrinkled1 transcription factor type AP2 in Arabidopsis thaliana (AtWRI), whose main function is to regulate lipid biosynthesis in plants, and they transferred it in the microalgae Nannochloropsis salina [188]. The characterization of the transformed cells revealed that the total lipid content increased by $36.5 \%$ compared to the wild-type strain.

One of the best methods in the genetic engineering approach uses the RNA silencing technique. Deng et al. investigated the $\mathrm{CrCO}$ gene of C. reinhardtii [189], a homologous gene of the circadian-regulated $\mathrm{CON}$ STANS gene (CO) which plays an important role in the photoperiod and flowering time [190, 191]. They determined that the repression and overexpression of the $\mathrm{CrCO}$ gene can change lipid accumulation in microalgae cells and the silencing of the gene (by RNA interference, RNAi) can increase the lipid content and the levels of TAGs up to $24 \%$. Trentacoste et al. reported that the gene knockout of a multifunctional lipase/ phospholipase/acyltransferase increased the amount of lipids in the cell without affecting the growth of the T. pseudonana diatom [192]. In addition, they discovered that antisense-mediated knockout mutants of the diatom had 3.3 times more lipid content than the wildtype variants in the exponential phase of growth.

There are many other experiments and reports based on the genetic engineering methods applied to the various species of microalgae (Table 5). However, these methods have some limitations: high production cost, low growth rate, low transformation success and incomplete genetic and characterization problems for the scaling of microalgae culture [51, 193, 194].

One problem of working with genetically modified (GM) microalgae is the environmental impacts and the ethics regarding their release. It is worthy to note that, the intentional release of GM organisms such as microalgae into the natural environment must be thoroughly analyzed and accepted by different international committees of experts; since in the error or consensual release of GM microalgae, they can remain in the natural habitat but even reproduce and spread further [195]. This concern related to GM microalgae and the impact to the environment and human health needs to be check by the negative ecological effects like change of food webs structure, 
Table 5 Improvement of lipid content in different species of microalgae with genetic engineering methods

\begin{tabular}{|c|c|c|c|}
\hline Microalgae species or strain & Type of modification & $\begin{array}{l}\text { Changes in lipid profile in the microalgal } \\
\text { cells }\end{array}$ & Refs. \\
\hline Chlamydomonas reinhardtii & $\begin{array}{l}\text { Repression of Major lipid droplet protein } \\
\text { (MLDP) gene expression }\end{array}$ & $\begin{array}{l}40 \% \text { increase in the average lipid droplet } \\
\text { diameter }\end{array}$ & {$[197]$} \\
\hline Chlamydomonas reinhardtii & Knockout of citrate synthase gene & TAG level increased up to $169.5 \%$ & {$[198]$} \\
\hline Chlamydomonas reinhardtii & $\begin{array}{l}\text { Artificial silencing of Diacylglycerol acyltrans- } \\
\text { ferase } 2-4 \text { gene (CrDGAT2-4) }\end{array}$ & 24\%-34\% increase in lipid content & {$[199]$} \\
\hline Chlamydomonas reinhardtii (starchless mutant) & $\begin{array}{l}\text { Inactivation of Adenosine diphosphoglucose } \\
\text { pyrophosphorylase (ADP-glucose pyrophos- } \\
\text { phorylase) }\end{array}$ & 10-fold increase in TAG & {$[200]$} \\
\hline Chlorella minutissima UTEX 2219 & $\begin{array}{l}\text { Overexpression of glycerol-3-phosphate } \\
\text { aceyltransferease gene, lysophosphatidic } \\
\text { acetyltransferase gene and diglyceride } \\
\text { acyltransferase }\end{array}$ & 2-fold increase in lipid content & {$[201]$} \\
\hline Scenedesmus obliquus (starchless mutant) & Knockdown of competitive pathways genes & Increase in TAG accumulation of up to $51 \%$ & [202] \\
\hline Phaeodactylum tricornutum & $\begin{array}{l}\text { Heterologous gene expression of acyl-acyl } \\
\text { carrier protein thioesterases (Acyl-ACP } \\
\text { thioesterases) }\end{array}$ & $\begin{array}{l}\text { Increased accumulation of shorter chain } \\
\text { length fatty acids }\end{array}$ & {$[203]$} \\
\hline Synechocystis sp. & Cyanophycin synthetase gene deletion & Fatty acids secretion into the medium & {$[204]$} \\
\hline Synechocystis sp. & Phosphotransacetylase gene deletion & Increase in production of fatty acids & {$[204]$} \\
\hline Phaeodactylum tricornutum & Suppression of TAG lipase gene expression & $\begin{array}{l}\text { Increase of the lipid content }(0.04 \pm 0.01 \mathrm{mg} \\
\mathrm{TAG} / \mathrm{mg} \text { dry weight) }\end{array}$ & {$[205]$} \\
\hline Scenedesmus obliquus & $\begin{array}{l}\text { Successful expression of diacylglycerol acyl- } \\
\text { transferase gene }\end{array}$ & Enhanced $128 \%$ of lipid content. & {$[190]$} \\
\hline C. reinhardtii & Knock-down of PEPC enzyme with CRISPRi & Enhanced lipid production up to 94\% & {$[191]$} \\
\hline P. tricornutum & Expression of malic enzyme & $\begin{array}{l}\text { Enhanced lipid productivity by } 2.5 \text { in compari- } \\
\text { son with wild-type }\end{array}$ & {$[192]$} \\
\hline P. tricornutum & $\begin{array}{l}\text { Overexpression of glucose-6-phosphate dehy- } \\
\text { drogenase (G6PD) }\end{array}$ & $\begin{array}{l}\text { Increased production of lipids up to } 55.7 \% \text { of } \\
\text { dry weight }\end{array}$ & {$[186]$} \\
\hline T.pseudonana & $\begin{array}{l}\text { Knock-down of a multifunctional lipase/phos- } \\
\text { pholipase/acetyltransferase enzyme }\end{array}$ & $\begin{array}{l}\text { Mutant strains produced 2.4- to 3.3-fold higher } \\
\text { amounts of lipids in comparison with wild- } \\
\text { type }\end{array}$ & {$[186]$} \\
\hline
\end{tabular}

displacing native species such as phytoplankton, causing local extinctions, detrimental algal blooms formation, and having serious societal, cultural and economic effects where different toxic strains are involved [196]; in order to make a final decision about their release.

Other examples related to genetic modifications of microalgae to improve resistance and that could be useful to improve lipid content/productivity: one was carried out by Nakamoto and colleagues [194, 195], the small heat shock protein (ch-sHSP) was overexpressed in Synechococcus elongates resulting in higher thermo tolerance under light condition (in comparison with wild-type). Schroda and collaborators [194] overexpressed HSP70B in Chlamydomonas and find that exhibited greater photosynthetic efficiency by protecting the photosystem II. Finally, Li and colleagues [197] overexpressed the homogentisate phytyltransferase vitamin E2 (VTE2) obtaining a higher protection against oxidative stress.

\section{Conclusion}

Microalgae as unicellular photosynthetic microorganisms can produce high amounts of lipids, which makes them a promise for biofuel production in the sustainable energy sector. Most importantly the growth of microalgae, their maintenance, the extraction of lipids and their subsequent conversion to biofuels must be profitable and competitive with fossil fuels. This review has shown different environmental and genetic engineering strategies that have been explored in order to achieve increased lipid production in different microalgae species and therefore an economically feasible strategy of energy production. These strategies can be used alone or in combination, however, it is necessary to carry out more studies. It is also important to remember that the effectiveness of the strategies and their results will depend on the species, the lipid production objective, the experimental facilities available and the economic resources accessible to the development of the project. 


\section{Authors' contributions}

All authors contributed to the writing of this review. All authors read and approved the final manuscript.

\section{Funding}

The Universidad Autónoma de Nuevo León and CONACyT for providing financial support through Paicyt 2016-2017 Science Grant from the Universidad Autónoma de Nuevo León. CONACyT Grants for: Basic science grant 221332, Fronteras de la Ciencia grant 1502 and Infraestructura Grant 279957.

\section{Availability of data and materials}

The datasets used and/or analyzed during the current study are available from the corresponding author on reasonable request.

\section{Ethics approval and consent to participate}

Not applicable.

\section{Consent for publication}

Not applicable.

\section{Competing interests}

The authors declare that they have no competing interests.

\section{Author details}

${ }^{1}$ Facultad de Ciencias Químicas, Universidad Autónoma de Nuevo León, UANL, Av. Universidad s/n, CD. Universitaria, 66451 San Nicolás de los Garza, NL, Mexico. ${ }^{2}$ Centro de Investigación en Biotecnología y Nanotecnología, Facultad de Ciencias Químicas, Universidad Autónoma de Nuevo León, Parque de Investigación e Innovación Tecnológica, Km. 10 autopista al Aeropuerto Internacional Mariano Escobedo, 66629 Apodaca, Nuevo León, Mexico. ${ }^{3}$ Department of Crop Production and Plant Breeding, School of Agriculture, Shiraz University, Km. 12 Shiraz-Isfahan Highway, Bajgah Area, Shiraz 71441-65186, Iran. ${ }^{4}$ Facultad de Ciencias Biológicas, Universidad Autónoma de Nuevo León, UANL, Av. Universidad s/n, CD. Universitaria, 66451 San Nicolás de los Garza, $\mathrm{NL}$, Mexico.

Received: 31 July 2019 Accepted: 4 October 2019

Published online: 21 October 2019

\section{References}

1. Rebello V, Shaikh S, Desai P. Toxicity of cobalt oxide nanoparticles. In: 2010 International conference on environmental engineering and applications (ICEEA). New York: IEEE; 2010.

2. Zhu L, Li Z, Hiltunen E. Strategies for lipid production improvement in microalgae as a biodiesel feedstock. BioMed Res Int. 2016;2016:8.

3. Dincer I. Renewable energy and sustainable development: a crucial review. Renew Sustain Energy Rev. 2000;4(2):157-75.

4. Ng IS, et al. Recent developments on genetic engineering of microalgae for biofuels and bio-based chemicals. Biotechnol J. 2017;12(10):1600644.

5. Gunatilake H, Roland-Holst D, Sugiyarto G. Energy security for India: biofuels, energy efficiency and food productivity. Energy Policy. 2014;65:761-7.

6. Zhu L, Huo S, Qin L. A microalgae-based biodiesel refinery: sustainability concerns and challenges. Int J Green Energy. 2015;12(6):595-602.

7. Chanthawong A, Dhakal S. Stakeholders' perceptions on challenges and opportunities for biodiesel and bioethanol policy development in Thailand. Energy Policy. 2016;91:189-206.

8. Goldemberg J. The promise of clean energy. Energy Policy. 2006:34(15):2185-90.

9. Panwar N, Kaushik S, Kothari S. Role of renewable energy sources in environmental protection: a review. Renew Sustain Energy Rev. 2011;15(3):1513-24.

10. Hill J, et al. Environmental, economic, and energetic costs and benefits of biodiesel and ethanol biofuels. Proc Natl Acad Sci. 2006:103(30):11206-10

11. Dahiya A. Bioenergy: biomass to biofuels. Cambridge: Academic Press; 2014
12. Brennan $L$, Owende P. Biofuels from microalgae-a review of technologies for production, processing, and extractions of biofuels and co-products. Renew Sustain Energy Rev. 2010;14(2):557-77.

13. Naik SN, et al. Production of first and second generation biofuels: a comprehensive review. Renew Sustain Energy Rev. 2010;14(2):578-97.

14. Kalnes T, Marker T, Shonnard DR. Green diesel: a second generation biofuel. Int J Chem React Eng. 2007;5(1):A48.

15. Zhu L. Microalgal culture strategies for biofuel production: a review. Biofuels Bioprod Biorefin. 2015;9(6):801-14

16. Zhu L-D, et al. Algal biorefinery for sustainable development and the challenges. Proc Inst Civil Eng Energy. 2016;169(4):179-86.

17. Abomohra AE-F, El-Sheekh M, Hanelt D. Screening of marine microalgae isolated from the hypersaline Bardawil lagoon for biodiesel feedstock. Renew Energy. 2017;101:1266-72.

18. Gordon ME, Cook AT. Challenge and potential of biofuels from algae-ft. Science. 2016;2016:e00264.

19. Han F, et al. Beneficial changes in biomass and lipid of microalgae Anabaena variabilis facing the ultrasonic stress environment. Bioresour Technol. 2016;209:16-22.

20. Zhu $\mathrm{L}$. The combined production of ethanol and biogas from microalgal residuals to sustain microalgal biodiesel: a theoretical evaluation. Biofuels Bioprod Biorefin. 2014;8(1):7-15.

21. Medipally SR, et al. Microalgae as sustainable renewable energy feedstock for biofuel production. BioMed Res Int. 2015:2015:13.

22. Molinuevo-Salces B, García-González MC, González-Fernández C. Performance comparison of two photobioreactors configurations (open and closed to the atmosphere) treating anaerobically degraded swine slurry. Bioresour Technol. 2010;101(14):5144-9.

23. Anjos $\mathrm{M}$, et al. Optimization of $\mathrm{CO} 2$ bio-mitigation by Chlorella vulgaris. Bioresour Technol. 2013;139:149-54.

24. De Godos I, et al. Simultaneous nutrients and carbon removal during pretreated swine slurry degradation in a tubular biofilm photobioreactor. Appl Microbiol Biotechnol. 2009;82(1):187-94.

25. Park KY, Lim B-R, Lee K. Growth of microalgae in diluted process water of the animal wastewater treatment plant. Water Sci Technol. 2009;59(11):2111-6.

26. Miao $X$, Wu Q. Biodiesel production from heterotrophic microalgal oil Bioresour Technol. 2006:97(6):841-6.

27. Widjaja A, Chien C-C, Ju Y-H. Study of increasing lipid production from fresh water microalgae Chlorella vulgaris. J Taiwan Inst Chem Eng. 2009;40(1):13-20

28. Demirbas A. Use of algae as biofuel sources. Energy Convers Manage. 2010;51(12):2738-49.

29. Milne TA, Evans RJ, Nagle N. Catalytic conversion of microalgae and vegetable oils to premium gasoline, with shape-selective zeolites. Biomass. 1990:21(3):219-32.

30. Sahu AK, Rusten B. Microalgae growth for nutrient recovery from sludge liquor and production of renewable bioenergy. Proc Water Environ Fed. 2011;2011(1):132-43.

31. Salerno M, Nurdogan Y, Lundquist TJ. Biogas production from algae biomass harvested at wastewater treatment ponds. St. Joseph: American Society of Agricultural and Biological Engineers; 2009.

32. Ozkurt I. Qualifying of safflower and algae for energy. Energy Educ Sci Technol Part a Energy Sci Res. 2009;23(1-2):145-51.

33. Vitova $M$, et al. Accumulation of energy reserves in algae: from cell cycles to biotechnological applications. Biotechnol Adv. 2015:33(6):1204-18.

34. Mathieu-Rivet $\mathrm{E}$, et al. Protein N-glycosylation in eukaryotic microalgae and its impact on the production of nuclear expressed biopharmaceuticals. Front Plant Sci. 2014:5:359.

35. Solovchenko A. Physiological role of neutral lipid accumulation in eukaryotic microalgae under stresses. Russ J Plant Physiol. 2012;59(2):167-76.

36. Fukuda $\mathrm{H}$, Kondo A, Noda $\mathrm{H}$. Biodiesel fuel production by transesterification of oils. J Biosci Bioeng. 2001;92(5):405-16.

37. Chisti Y. Biodiesel from microalgae beats bioethanol. Trends Biotechnol. 2008;26(3):126-31.

38. Zhu L, et al. Oil production from pilot-scale microalgae cultivation: an economics evaluation. Energy Sour Part B. 2016;11(1):11-7. 
39. Doroszuk A, et al. Transcriptome analysis of a long-lived natural Drosophila variant: a prominent role of stress-and reproduction-genes in lifespan extension. BMC Genomics. 2012;13(1):167.

40. Althoff T, et al. Arrangement of electron transport chain components in bovine mitochondrial supercomplex I 1 III 2 IV 1 . EMBO J. 2011;30(22):4652-64.

41. Yates CM, Calder PC, Rainger GE. Pharmacology and therapeutics of omega-3 polyunsaturated fatty acids in chronic inflammatory disease. Pharmacol Ther. 2014;141(3):272-82.

42. Gopalakrishnan V, Ramamurthy D. Dyeing industry effluent system as lipid production medium of Neochloris sp. for biodiesel feedstock preparation. BioMed Res Int. 2014;2014:7.

43. Fan J, Yu L, Xu C. A central role for triacylglycerol in membrane lipid breakdown, fatty acid $\beta$-oxidation, and plant survival under extended darkness. Plant Physiol. 2017;174(3):1517-30.

44. Murphy DJ, Leech RM. Photosynthesis of lipids from $14 \mathrm{CO}_{2}$ in Spinacia oleracea. Plant Physiol. 1981;68(3):762-5.

45. Liang $\mathrm{M}-\mathrm{H}$, Jiang J-G. Advancing oleaginous microorganisms to produce lipid via metabolic engineering technology. Prog Lipid Res. 2013;52(4):395-408.

46. Bates PD, Browse J. The significance of different diacylgycerol synthesis pathways on plant oil composition and bioengineering. Front Plant Sci. 2012;3:147.

47. Bates PD, Stymne S, Ohlrogge J. Biochemical pathways in seed oil synthesis. Curr Opin Plant Biol. 2013;16(3):358-64.

48. Xu C, Shanklin J. Triacylglycerol metabolism, function, and accumulation in plant vegetative tissues. Annu Rev Plant Biol. 2016;67:179-206.

49. Chen $\mathrm{H}-\mathrm{H}$, Jiang J-G. Lipid accumulation mechanisms in auto-and heterotrophic microalgae. J Agric Food Chem. 2017:65(37):8099-110.

50. Thompson GA Jr. Lipids and membrane function in green algae. Biochim et Biophys Acta (BBA) Lipids Lipid Metab. 1996;1302(1):17-45.

51. Sharma KK, Schuhmann H, Schenk PM. High lipid induction in microalgae for biodiesel production. Energies. 2012;5(5):1532-53.

52. Cohen Z, Vonshak A, Richmond A. Effect of environmental conditions on fatty acid composition of the red alga Porphyridium cruentum: correlation to growth rate. J Phycol. 1988;24(3):328-32.

53. Bigogno $C$, et al. Lipid and fatty acid composition of the green oleaginous alga Parietochloris incisa, the richest plant source of arachidonic acid. Phytochemistry. 2002;60(5):497-503.

54. Khozin-Goldberg I, et al. Nitrogen starvation induces the accumulation of arachidonic acid in the freshwater green alga Parietochloris incisa (Trebuxiophyceae). J Phycol. 2002;38(5):991-4.

55. Berge J-P, et al. Reassessment of lipid composition of the diatom, Skeletonema costatum. Phytochemistry. 1995;39(5):1017-21.

56. Eizadora TY, et al. Triacylglycerol accumulation and profiling in the model diatoms Thalassiosira pseudonana and Phaeodactylum tricornutum (Baccilariophyceae) during starvation. J Appl Phycol. 2009;21(6):669.

57. Khozin-Goldberg I, Cohen Z. The effect of phosphate starvation on the lipid and fatty acid composition of the fresh water eustigmatophyte Monodus subterraneus. Phytochemistry. 2006;67(7):696-701.

58. Makewicz A, Gribi C, Eichenberger W. Lipids of Ectocarpus fasciculatus (phaeophyceae). Incorporation of [1-14C] oleate and the role of TAG and MGDG in lipid metabolism. Plant Cell Physiol. 1997;38(8):952-62.

59. Chiu S-Y, et al. Lipid accumulation and $\mathrm{CO} 2$ utilization of Nannochloropsis oculata in response to $\mathrm{CO}_{2}$ aeration. Bioresour Technol. 2009;100(2):833-8.

60. Demirbas A, Demirbas MF. Importance of algae oil as a source of biodiesel. Energy Convers Manage. 2011;52(1):163-70.

61. Severes A, et al. Use of light emitting diodes (LEDs) for enhanced lipid production in micro-algae based biofuels. J Photochem Photobiol B. 2017;170:235-40.

62. Wong $Y-K$, et al. Effect of different light sources on algal biomass and lipid production in internal leds-illuminated photobioreactor. J Mar Biol Aquacult. 2016;2(2):1-8.

63. Al-Alwani MA, et al. Dye-sensitised solar cells: development, structure, operation principles, electron kinetics, characterisation, synthesis materials and natural photosensitisers. Renew Sustain Energy Rev. 2016;65:183-213.
64. Rai MP, Gautom T, Sharma N. Effect of salinity, pH, light intensity on growth and lipid production of microalgae for bioenergy application. OnLine J Biol Sci. 2015;15(4):260.

65. Osman SM, et al. Light-color-induced changes in fatty acid biosynthesis in Chlorella sp. strain Ks-ma2 in early stationary growth phase. BIOTROPIA Southeast Asian J Trop Biol. 2018;25(1):33-42.

66. Markou G. Effect of various colors of light-emitting diodes (LEDs) on the biomass composition of Arthrospira platensis cultivated in semi-continuous mode. Appl Biochem Biotechnol. 2014;172(5):2758-68.

67. Liu J, et al. Effects of light intensity on the growth and lipid accumulation of microalga Scenedesmus sp. 11-1 under nitrogen limitation. Appl Biochem Biotechnol. 2012;166(8):2127-37.

68. Marchetti J, et al. Effects of blue light on the biochemical composition and photosynthetic activity of Isochrysis sp. (T-iso). J Appl Phycol. 2013;25(1):109-19.

69. Wacker $A$, et al. Light-induced changes in fatty acid profiles of specific lipid classes in several freshwater phytoplankton species. Front Plant Sci. 2016;7:264.

70. Gammanpila AM, Rupasinghe CP, Subasinghe S. Light intensity and photo period effect on growth and lipid accumulation of microalgae chlorella vulgaris and Nannochloropsis sp. for biodiesel production. In: 12th ISERD international conference; 2015. Tokyo, Japan.

71. Solovchenko A, et al. Effects of light intensity and nitrogen starvation on growth, total fatty acids and arachidonic acid in the green microalga Parietochloris incisa. J Appl Phycol. 2008;20(3):245-51.

72. Hallenbeck PC, et al. The use of design of experiments and response surface methodology to optimize biomass and lipid production by the oleaginous marine green alga, Nannochloropsis gaditana in response to light intensity, inoculum size and $\mathrm{CO}_{2}$. Bioresour Technol. 2015;184:161-8

73. Pal D, et al. The effect of light, salinity, and nitrogen availability on lipid production by Nannochloropsis sp. Appl Microbiol Biotechnol. 2011;90(4):1429-41.

74. Takeshita T, et al. Starch and lipid accumulation in eight strains of six Chlorella species under comparatively high light intensity and aeration culture conditions. Bioresour Technol. 2014;158:127-34.

75. Seo SH, et al. Light intensity as major factor to maximize biomass and lipid productivity of Ettlia sp. in $\mathrm{CO}_{2}$-controlled photoautotrophic chemostat. Bioresour Technol. 2017;244:621-8.

76. Breuer $\mathrm{G}$, et al. Effect of light intensity, $\mathrm{pH}$, and temperature on triacylglycerol (TAG) accumulation induced by nitrogen starvation in Scenedesmus obliquus. Bioresour Technol. 2013;143:1-9.

77. Jerney J, Spilling K. Large scale cultivation of microalgae: open and closed systems. In: Methods in molecular biology. Totowa, New Jersey: Humana Press; 2018. https://doi.org/10.1007/7651_2018_130.

78. Narala RR, et al. Comparison of microalgae cultivation in photobioreactor, open raceway pond, and a two-stage hybrid system. Front Energy Res. 2016;4:29.

79. Sing SF, et al. Production of biofuels from microalgae. Mitig Adapt Strat Glob Change. 2013;18(1):47-72.

80. Mata TM, Martins AA, Caetano NS. Microalgae for biodiesel produc tion and other applications: a review. Renew Sustain Energy Rev. 2010;14(1):217-32.

81. Qin L, Alam MA, Wang Z. Open pond culture systems and photobioreactors for microalgal biofuel production. Microalgae biotechnology for development of biofuel and wastewater treatment. Berlin: Springer; 2019. p. 45-74.

82. Huesemann M, Benemann J. Biofuels from microalgae: review of products. Processes and potential, with special focus on Dunaliella sp. Enfield: Science Publishers; 2009.

83. Jorquera $\mathrm{O}$, et al. Comparative energy life-cycle analyses of microalgal biomass production in open ponds and photobioreactors. Bioresour Technol. 2010;101(4):1406-13.

84. Fernández FA, Sevilla JF, Grima EM. Photobioreactors for the production of microalgae. Rev Environ Sci Bio/Technol. 2013;12(2):131-51.

85. Fan KW, Chen F. Production of high-value products by marine microalgae Thraustochytrids. Bioprocessing for value-added products from renewable resources. Amsterdam: Elsevier; 2007. p. 293-323.

86. Bosma R, et al. Prediction of volumetric productivity of an outdoor photobioreactor. Biotechnol Bioeng. 2007;97(5):1108-20. 
87. $\mathrm{Xu} \mathrm{L,} \mathrm{et} \mathrm{al.} \mathrm{Microalgal} \mathrm{bioreactors:} \mathrm{challenges} \mathrm{and} \mathrm{opportunities.} \mathrm{Eng}$ Life Sci. 2009;9(3):178-89.

88. Kamyaba $\mathrm{H}$, et al. Role of microalgal biotechnology in environmental sustainability—a mini review. Chem Eng. 2019. https://doi.org/10.3303/ CET1972076.

89. B., S. Utilizing algae's potential for a better tomorrow; 2011. https://phys. org/news/2011-01-algae-potential-tomorrow.html. Accessed 20 Jun 2019

90. Marsullo M, et al. Dynamic modeling of the microalgae cultivation phase for energy production in open raceway ponds and flat panel photobioreactors. Front Energy Res. 2015;3:41.

91. Hermans K, Slager B. Greenhouse for enhanced plant growth; 2011, Google Patents.

92. Besuijen H. Large-scale algae production in greenhouses-modelling technical design and economic analysis; 2014. https://www.wur.nl/en/ newsarticle/Largescale-algae-production-in-greenhouses-Modellingtechnical-design-and-economic-analysis.htm. Accessed 20 Jun 2019.

93. Wang $\mathrm{B}$, et al. $\mathrm{CO}_{2}$ bio-mitigation using microalgae. Appl Microbiol Biotechnol. 2008;79(5):707-18.

94. Singh $\mathrm{S}$, Singh P. Effect of $\mathrm{CO}_{2}$ concentration on algal growth: a review. Renew Sustain Energy Rev. 2014;38:172-9.

95. de Morais MG, Costa JAV. Isolation and selection of microalgae from coal fired thermoelectric power plant for biofixation of carbon dioxide. Energy Convers Manage. 2007:48(7):2169-73.

96. Hoshida $\mathrm{H}$, et al. Accumulation of eicosapentaenoic acid in Nannochloropsis sp. in response to elevated $\mathrm{CO}_{2}$ concentrations. J Appl Phycol. 2005:17(1):29-34.

97. Ying $\mathrm{K}$, Zimmerman W, Gilmour D. Effects of $\mathrm{CO}$ and $\mathrm{pH}$ on growth of the microalga Dunaliella salina. J Microbial Biochem Technol. 2014;6(3):167-73.

98. Mondal M, et al. Role of carbonic anhydrase on the way to biological carbon capture through microalgae - a mini review. Environ Prog Sustain Energy. 2016:35(6):1605-15.

99. Nakanishi A, et al. Development of lipid productivities under different $\mathrm{CO}_{2}$ conditions of marine microalgae Chlamydomonas sp. JSC4. Bioresour Technol. 2014;152:247-52.

100. Ota M, et al. Fatty acid production from a highly $\mathrm{CO} 2$ tolerant alga, Chlorocuccum littorale, in the presence of inorganic carbon and nitrate. Bioresour Technol. 2009;100(21):5237-42.

101. Ho S-H, Chen C-Y, Chang J-S. Effect of light intensity and nitrogen starvation on $\mathrm{CO}_{2}$ fixation and lipid/carbohydrate production of an indigenous microalga Scenedesmus obliquus CNW-N. Bioresour Technol. 2012;113:244-52.

102. Cuellar-Bermudez SP, et al. Effects of light intensity and carbon dioxide on lipids and fatty acids produced by Synechocystis sp. PCC6803 during continuous flow. Algal Res. 2015;12:10-6.

103. Artamonova E, Vasskog T, Eilertsen HC. Lipid content and fatty acid composition of Porosira glacialis and Attheya longicornis in response to carbon dioxide $\left(\mathrm{CO}_{2}\right)$ aeration. PLoS ONE. 2017;12(5):e0177703.

104. Krishnan V, Uemura Y, Thanh NT, Khalid NA, Osman N, Mansor N. Three types of Marine microalgae and Nannocholoropsis oculata cultivation for potential source of biomass production. J Phys: Conf Ser. 2015:622(1):012034

105. Yoo C, et al. Selection of microalgae for lipid production under high levels carbon dioxide. Bioresour Technol. 2010;101(1):S71-4.

106. Huang Y, Su C. High lipid content and productivity of microalgae cultivating under elevated carbon dioxide. Int J Environ Sci Technol. 2014;11(3):703-10.

107. Ortiz Montoya EY, et al. Production of Chlorella vulgaris as a source of essential fatty acids in a tubular photobioreactor continuously fed with air enriched with $\mathrm{CO}_{2}$ at different concentrations. Biotechnol Prog. 2014;30(4):916-22.

108. Bagchi SK, Mallick N. Carbon dioxide biofixation and lipid accumulation potential of an indigenous microalga Scenedesmus obliquus (Turpin) Kützing GA 45 for biodiesel production. RSC Adv. 2016;6(36):29889-98.

109. Dickinson $S$, et al. A review of biodiesel production from microalgae. Clean Technol Environ Policy. 2017;19(3):637-68.

110. Menegol T, et al. Effect of temperature and nitrogen concentration on biomass composition of Heterochlorella luteoviridis. Food Sci Technol. 2017;37(SPE):28-37.
111. Freire I, et al. Nannochloropsis limnetica: a freshwater microalga for marine aquaculture. Aquaculture. 2016;459:124-30.

112. Converti $\mathrm{A}$, et al. Effect of temperature and nitrogen concentration on the growth and lipid content of Nannochloropsis oculata and Chlorella vulgaris for biodiesel production. Chem Eng Process. 2009;48(6):1146-51.

113. Bohnenberger JE, Crossetti LO. Influence of temperature and nutrient content on lipid production in freshwater microalgae cultures. An Acad Bras Ciênc. 2014;86(3):1239-48.

114. Wei L, Huang X, Huang Z. Temperature effects on lipid properties of microalgae Tetraselmis subcordiformis and Nannochloropsis oculata as biofuel resources. Chin J Oceanol Limnol. 2015;33(1):99-106.

115. Arguelles ED, et al. Fatty acid profile and fuel-derived physico-chemical properties of biodiesel obtained from an indigenous green microalga, Desmodesmus sp. (I-AU1), as potential source of renewable lipid and high quality biodiesel. J Appl Phycol. 2018;30(1):411-9.

116. Yeh KL, Chang JS. Nitrogen starvation strategies and photobioreactor design for enhancing lipid content and lipid production of a newly isolated microalga Chlorella vulgaris ESP-31: implications for biofuels. Biotechnol J. 2011:6(11):1358-66.

117. Praveenkumar $R$, et al. Influence of nutrient deprivations on lipid accumulation in a dominant indigenous microalga Chlorella sp., BUM11008: evaluation for biodiesel production. Biomass Bioenergy. 2012;37:60-6.

118. Hsieh C-H, Wu W-T. Cultivation of microalgae for oil production with a cultivation strategy of urea limitation. Bioresour Technol. 2009;100(17):3921-6.

119. Li Y, et al. Potential lipid accumulation and growth characteristic of the green alga Chlorella with combination cultivation mode of nitrogen (N) and phosphorus (P). Bioresour Technol. 2014;174:24-32.

120. Srinuanpan S, et al. Strategies to increase the potential use of oleaginous microalgae as biodiesel feedstocks: nutrient starvations and cost-effective harvesting process. Renew Energy. 2018;122:507-16.

121. Yang $L$, et al. Growth and lipid accumulation by different nutrients in the microalga Chlamydomonas reinhardtii. Biotechnol Biofuels. 2018;11(1):40.

122. Cordeiro RS, et al. Effects of nutritional conditions on lipid production by cyanobacteria. Anais da Academia Brasileira de Ciências. 2017:89:2021-31.

123. Mata TM, Almeidab R, Caetanoa NS. Effect of the culture nutrients on the biomass and lipid productivities of microalgae Dunaliella tertiolecta. Chem Eng. 2013;32:973.

124. Janssen PJ, et al. The complete genome sequence of Cupriavidus metallidurans strain $\mathrm{CH} 34$, a master survivalist in harsh and anthropogenic environments. PLoS ONE. 2010;5(5):e10433.

125. Nicolau R, Galera-Cunha A, Lucas Y. Transfer of nutrients and labile metals from the continent to the sea by a small Mediterranean river. Chemosphere. 2006;63(3):469-76.

126. Kar D, et al. Assessment of heavy metal pollution in surface water. Int J Environ Sci Technol. 2008:5(1):119-24.

127. Ndeezi G, et al. Zinc status in HIV infected Ugandan children aged 1-5 years: a cross sectional baseline survey. BMC Pediatr. 2010;10(1):68

128. Munda IM, Hudnik V. The effects of $\mathrm{Zn}, \mathrm{Mn}$, and Co accumulation on growth and chemical composition of Fucus vesiculosus $L$. under different temperature and salinity conditions. Mar Ecol. 1988;9(3):213-25.

129. Jennett JC, Hassett JM, Smith JE. The use of algae to control heavy metals in the environment. Min Environ. 1980;2(1):26-31.

130. Srivastava $V$, et al. Biochemical, physiological, and yield responses of lady's finger (Abelmoschus esculentus L.) grown on varying ratios of municipal solid waste vermicompost. Int J Recycl Org Waste Agric. 2018:7:1-10.

131. Van Assche F, Clijsters H. Effects of metals on enzyme activity in plants. Plant Cell Environ. 1990;13(3):195-206.

132. Sharmin N, et al. Effect of boron addition on the thermal, degradation, and cytocompatibility properties of phosphate-based glasses. BioMed Res Int. 2013;2013:12.

133. Ren H-Y, et al. Enhanced lipid accumulation of green microalga Scenedesmus sp. by metal ions and EDTA addition. Bioresour Technol. 2014:169:763-7.

134. Einicker-Lamas $\mathrm{M}$, et al. Euglena gracilis as a model for the study of $\mathrm{Cu}_{2}+$ and $\mathrm{Zn}_{2}+$ toxicity and accumulation in eukaryotic cells. Environ Pollut. 2002:120(3):779-86. 
135. Liu Z-Y, Wang G-C, Zhou B-C. Effect of iron on growth and lipid accumulation in Chlorella vulgaris. Bioresour Technol. 2008;99(11):4717-22.

136. Huang $L, X u J, L i T$, Wang $L$, Deng T, Yu X. Effects of additional $\mathrm{Mg}_{2}+$ on the growth, lipid production, and fatty acid composition of Monoraphidium sp. FXY-10 under different culture conditions. Ann Microbiol. 2014;64(3):1247-56.

137. Zhang $\mathrm{H}$, et al. Identification and characterization of $\mathrm{CBL}$ and CIPK gene families in canola (Brassica napus L.). BMC Plant Biol. 2014;14(1):8.

138. Berkowitz G, Wu W. Magnesium, potassium flux and photosynthesis. Magnes Res. 1993;6(3):257-65.

139. Shaul O. Magnesium transport and function in plants: the tip of the iceberg. Biometals. 2002;15(3):307-21.

140. Battah $\mathrm{M}$, et al. Effect of $\mathrm{Mn}_{2}+, \mathrm{CO}_{2}+$ and $\mathrm{H}_{2} \mathrm{O}_{2}$ on biomass and lipids of the green microalga Chlorella vulgaris as a potential candidate for biodiesel production. Ann Microbiol. 2015;65(1):155-62.

141. Alishah $\mathrm{H}$, et al. Green synthesis of starch-mediated $\mathrm{CuO}$ nanoparticles: preparation, characterization, antimicrobial activities and in vitro MTT assay against MCF-7 cell line. Rendiconti Lincei. 2017;28:1-7.

142. He M, et al. Improvement on lipid production by Scenedesmus obliquus triggered by low dose exposure to nanoparticles. Scientific Rep. 2017;7(1):15526

143. Kim Y-K, et al. Enhancement of bioethanol production in syngas fermentation with Clostridium ljungdahlii using nanoparticles. Bioresour Technol. 2014;159:446-50.

144. Zhu H, et al. Effect of functionalized MCM41 nanoparticles on syngas fermentation. Biomass Bioenerg. 2010;34(11):1624-7.

145. Ruthiya KC. Mass transfer and hydrodynamics in catalytic slurry reactors; Eindhoven: Technische Universiteit Eindhoven. 2005.

146. Jeon H-S, et al. Enhancement of biodiesel production in Chlorella vulgaris cultivation using silica nanoparticles. Biotechnol Bioprocess Eng. 2017;22(2):136-41.

147. Ahn B, et al. Effect of nanoparticle on cellular growth and lipid production in Chlorella vulgaris culture. Biotechnol Prog. 2018;34:929-33.

148. Reichelt K, et al. Phytochemical characterization of South African bush tea (Athrixia phylicoides DC.). S Afr J Bot. 2012;83:1-8.

149. Ji J, Long Z, Lin D. Toxicity of oxide nanoparticles to the green algae Chlorella sp. Chem Eng J. 2011;170(2-3):525-30.

150. Aruoja $\mathrm{V}$, et al. Toxicity of nanoparticles of $\mathrm{CuO}, \mathrm{ZnO}$ and $\mathrm{TiO}_{2}$ to microalgae Pseudokirchneriella subcapitata. Sci Total Environ. 2009:407(4):1461-8

151. Franklin NM, et al. Comparative toxicity of nanoparticulate $\mathrm{ZnO}$, bulk $\mathrm{ZnO}$, and $\mathrm{ZnCl}_{2}$ to a freshwater microalga (Pseudokirchneriella subcapitata): the importance of particle solubility. Environ Sci Technol. 2007;41(24):8484-90.

152. Alishah $\mathrm{H}$, et al. Extract-mediated synthesis of Ag@ AgCl nanoparticles using Conium maculatum seeds: characterization, antibacterial activity and cytotoxicity effect against MCF-7 cell line. RSC Adv. 2016;6(77):73197-202.

153. Alishah $\mathrm{H}$, et al. A green approach for the synthesis of silver nanoparticles using root extract of Chelidonium majus: characterization and antibacterial evaluation. J Clust Sci. 2016;27:1-9.

154. Chen X, et al. Toxicity of Co nanoparticles on three species of marine microalgae. Environ Pollut. 2018;236:454-61.

155. Nam S-H, Kwak J, An Y-J. Quantification of silver nanoparticle toxicity to algae in soil via photosynthetic and flow-cytometric analyses. Scientific Rep. 2018;8(1):292.

156. Aravantinou AF, et al. Effect of cultivation media on the toxicity of $\mathrm{ZnO}$ nanoparticles to freshwater and marine microalgae. Ecotoxicol Environ Saf. 2015;114:109-16.

157. Ayatallahzadeh Shirazi M, Shariati F, Ramezanpour Z. Toxicity effects of $\mathrm{SiO}_{2}$ nanoparticles on green micro-algae Dunaliella salina. Int J Nanosci Nanotechnol. 2016;12(4):269-75.

158. Arapatsakos C, Christoforidis D, Gkavaki S. The fuel temperature effect on the gas emissions when use as fuel diesel-palm + sunflower oil mixture. Proceedings of the 2nd WSEAS International Conference on URBAN PLANNING and TRANSPORTATION, pp 29-36, ISBN: 978-960-474-102-1.

159. Shirazi MA, Shariati F, Ramezanpour Z. Toxic effect of aluminum oxide nanoparticles on green micro-algae Dunaliella salina. Int J Environ Res. 2015;9(2):585-94.
160. Kang NK, et al. Enhancing lipid productivity of Chlorella vulgaris using oxidative stress by $\mathrm{TiO}_{2}$ nanoparticles. Korean J Chem Eng. 2014;31(5):861-7.

161. Hu Q, et al. Microalgal triacylglycerols as feedstocks for biofuel production: perspectives and advances. Plant J. 2008:54(4):621-39.

162. Sibi G, Ananda Kumar D, Gopal T, Harinath K, Banupriya S, Chaitra S. Metal nanoparticle triggered growth and lipid production in Chlorella vulgaris. Int I Scientific Res Environ Sci Toxicol. 2017;2(1):1-8.

163. Kadar $\mathrm{E}$, et al. The effect of engineered iron nanoparticles on growth and metabolic status of marine microalgae cultures. Sci Total Environ. 2012;439:8-17.

164. Sarma SJ, et al. Application of magnesium sulfate and its nanoparticles for enhanced lipid production by mixotrophic cultivation of algae using biodiesel waste. Energy. 2014;78:16-22.

165. Seo JY, et al. Downstream integration of microalgae harvesting and cell disruption by means of cationic surfactant-decorated $\mathrm{Fe}_{3} \mathrm{O}_{4}$ nanoparticles. Green Chem. 2016;18(14):3981-9.

166. Hu Y-R, et al. Efficient harvesting of marine microalgae Nannochloropsis maritima using magnetic nanoparticles. Bioresour Technol. 2013;138:387-90.

167. Guo DS, et al. Improving docosahexaenoic acid production by Schizochytrium sp. using a newly designed high-oxygen-supply bioreactor. AlChE J. 2017;63(10):4278-86.

168. Kalita N, et al. Ankistrodesmus falcatus: a promising candidate for lipid production, its biochemical analysis and strategies to enhance lipid productivity. J Microbiol Biotechnol Res. 2017;1 (4):148-57.

169. Mohan SV, Devi MP. Salinity stress induced lipid synthesis to harness biodiesel during dual mode cultivation of mixotrophic microalgae. Bioresour Technol. 2014;165:288-94.

170. Kan G, et al. Acclimatory responses to high-salt stress in Chlamydomonas (Chlorophyta, Chlorophyceae) from Antarctica. Acta Oceanol Sin. 2012;31(1):116-24.

171. Richmond A. CRC Handbook of microalgal mass culture. Boca Raton: CRC Press; 1986.

172. Bartley ML, et al. Effects of salinity on growth and lipid accumulation of biofuel microalga Nannochloropsis salina and invading organisms. Biomass Bioenerg. 2013;54:83-8.

173. Salama E-S, et al. Biomass, lipid content, and fatty acid composition of freshwater Chlamydomonas mexicana and Scenedesmus obliquus grown under salt stress. Bioprocess Biosyst Eng. 2013;36(6):827-33.

174. Pandit PR, Fulekar MH, Karuna MSL. Effect of salinity stress on growth, lipid productivity, fatty acid composition, and biodiesel properties in Acutodesmus obliquus and Chlorella vulgaris. Environ Sci Pollut Res. 2017;24(15):13437-51.

175. Chokshi K, et al. Salinity induced oxidative stress alters the physiological responses and improves the biofuel potential of green microalgae Acutodesmus dimorphus. Bioresour Technol. 2017;244:1376-83.

176. Srivastava G, Goud VV. Salinity induced lipid production in microalgae and cluster analysis (ICCB 16-BR_047). Bioresour Technol. 2017;242:244-52.

177. Lenka SK, et al. Current advances in molecular, biochemical, and computational modeling analysis of microalgal triacylglycerol biosynthesis. Biotechnol Adv. 2016:34(5):1046-63.

178. Song CW, Lee J, Lee SY. Genome engineering and gene expression control for bacterial strain development. Biotechnol J. 2015;10(1):56-68.

179. Shin S-E, et al. CRISPR/Cas9-induced knockout and knock-in mutations in Chlamydomonas reinhardtii. Scientific Rep. 2016;6:27810.

180. Kasai Y, et al. Construction of a self-cloning system in the unicellular green alga Pseudochoricystis ellipsoidea. Biotechnol Biofuels. 2015;8(1):94.

181. Sizova I, et al. Nuclear gene targeting in Chlamydomonas using engineered zinc-finger nucleases. Plant J. 2013;73(5):873-82.

182. Yao $\mathrm{L}$, et al. Multiple gene repression in cyanobacteria using CRISPRi. ACS Synth Biol. 2015;5(3):207-12.

183. Huang $\mathrm{C}-\mathrm{H}$, et al. CRISPR interference (CRISPRi) for gene regulation and succinate production in cyanobacterium S. elongatus PCC 7942. Microbial Cell Fact. 2016;15(1):196.

184. Vieler A, et al. Genome, functional gene annotation, and nuclear transformation of the heterokont oleaginous alga Nannochloropsis oceanica CCMP1779. PLoS Genet. 2012;8(11):e1003064. 
185. Shrestha A, Khan A, Dey N. Cis-trans engineering: advances and perspectives on customized transcriptional regulation in Plants. Mol Plant. 2018;11:886-98.

186. Yang B, et al. Chlorella species as hosts for genetic engineering and expression of heterologous proteins: progress, challenge and perspective. Biotechnol J. 2016;11(10):1244-61.

187. Dunahay TG, et al. Manipulation of microalgal lipid production using genetic engineering. Appl Biochem Biotechnol. 1996;57(1):223.

188. Kang NK, et al. Increased lipid production by heterologous expression of AtWRI1 transcription factor in Nannochloropsis salina. Biotechnol Biofuels. 2017;10(1):231.

189. Deng $X$, et al. A photoperiod-regulating gene CONSTANS is correlated to lipid biosynthesis in Chlamydomonas reinhardtii. BioMed Res Int. 2015;2015:12

190. Kobayashi Y, Weigel D. Move on up, it's time for change-mobile signals controlling photoperiod-dependent flowering. Genes Dev. 2007;21(19):2371-84.

191. Serrano G, et al. Chlamydomonas CONSTANS and the evolution of plant photoperiodic signaling. Curr Biol. 2009;19(5):359-68.

192. Trentacoste EM, et al. Metabolic engineering of lipid catabolism increases microalgal lipid accumulation without compromising growth. Proc Natl Acad Sci. 2013;110(49):19748-53.

193. Tabatabaei $M$, et al. Biodiesel production from genetically engineered microalgae: future of bioenergy in Iran. Renew Sustain Energy Rev. 2011;15(4):1918-27.

194. Singh P, et al. Trends and novel strategies for enhancing lipid accumulation and quality in microalgae. Renew Sustain Energy Rev. 2016;55:1-16

195. Beacham TA, Sweet JB, Allen MJ. Large scale cultivation of genetically modified microalgae: a new era for environmental risk assessment. Algal Res. 2017:25:90-100

196. Campbell ML. Assessing biosecurity risk associated with the importation of non-indigenous microalgae. Environ Res. 2011;111(7):989-98.
197. Moellering ER, Benning C. RNA interference silencing of a major lipid droplet protein affects lipid droplet size in Chlamydomonas reinhardtii. Eukaryot Cell. 2010;9(1):97-106

198. Deng X, Cai J, Fei X. Effect of the expression and knockdown of citrate synthase gene on carbon flux during triacylglycerol biosynthesis by green algae Chlamydomonas reinhardtii. BMC Biochem. 2013;14(1):38.

199. Deng X-D, et al. The roles of acyl-CoA: diacylglycerol acyltransferase 2 genes in the biosynthesis of triacylglycerols by the green algae Chlamydomonas reinhardtii. Mol Plant. 2012;5(4):945-7.

200. LiY, et al. Chlamydomonas starchless mutant defective in ADP-glucose pyrophosphorylase hyper-accumulates triacylglycerol. Metab Eng. 2010;12(4):387-91.

201. Hsieh H-J, Su C-H, Chien L-J. Accumulation of lipid production in Chlorella minutissima by triacylglycerol biosynthesis-related genes cloned from Saccharomyces cerevisiae and Yarrowia lipolytica. J Microbiol. 2012;50(3):526-34

202. de Jaeger $L$, et al. Superior triacylglycerol (TAG) accumulation in starchless mutants of Scenedesmus obliquus:(I) mutant generation and characterization. Biotechnol Biofuels. 2014;7(1):69.

203. Radakovits R, Eduafo PM, Posewitz MC. Genetic engineering of fatty acid chain length in Phaeodactylum tricornutum. Metab Eng 2011;13(1):89-95.

204. Liu X, Sheng J, Curtiss R III. Fatty acid production in genetically modified cyanobacteria. Proc Natl Acad Sci. 2011;108:6899-904.

205. Bode $\mathrm{H}$, et al. Increasing the lipid content in microalgae by genetically manipulating a triacylglycerol (tag) lipase; 2014. Google Patents.

\section{Publisher's Note}

Springer Nature remains neutral with regard to jurisdictional claims in published maps and institutional affiliations.
Ready to submit your research? Choose BMC and benefit from:

- fast, convenient online submission

- thorough peer review by experienced researchers in your field

- rapid publication on acceptance

- support for research data, including large and complex data types

- gold Open Access which fosters wider collaboration and increased citations

- maximum visibility for your research: over 100M website views per year

At $\mathrm{BMC}$, research is always in progress.

Learn more biomedcentral.com/submissions 